\title{
Article \\ Probing Oxygen-to-Hydrogen Peroxide Electro-Conversion at Electrocatalysts Derived from Polyaniline
}

\author{
Yaovi Holade ${ }^{1, *(\mathbb{D}}$, Sarra Knani ${ }^{1}$, Marie-Agnès Lacour ${ }^{2}{ }^{\mathbb{D}}$, Julien Cambedouzou ${ }^{1} \mathbb{D}$, Sophie Tingry ${ }^{1}$, \\ Teko W. Napporn ${ }^{3}(D)$ and David Cornu ${ }^{1}$
}

1 Institut Européen des Membranes, IEM, UMR 5635, Univ Montpellier, ENSCM, CNRS, 34090 Montpellier, France; sarra.knani@umontpellier.fr (S.K.); julien.cambedouzou@enscm.fr (J.C.); sophie.tingry@umontpellier.fr (S.T.); david.cornu@enscm.fr (D.C.)

2 ChemLab, ENSCM, 34296 Montpellier, France; marie-agnes.lacour@enscm.fr

3 IC2MP, Université de Poitiers, UMR-CNRS 7285, CEDEX 9, 86073 Poitiers, France, teko.napporn@univ-poitiers.fr

* Correspondence: yaovi.holade@enscm.fr; Tel.: +33-467-149-294

\section{check for}

Citation: Holade, Y.; Knani, S.;

Lacour, M.-A.; Cambedouzou, J.; Tingry, S.; Napporn, T.W.; Cornu, D. Probing Oxygen-to-Hydrogen Peroxide Electro-Conversion at Electrocatalysts Derived from

Polyaniline. Polymers 2022, 14, 607. https://doi.org/10.3390/ polym 14030607

Academic Editor: Hai-Feng (Frank) Ji

Received: 31 December 2021

Accepted: 31 January 2022

Published: 4 February 2022

Publisher's Note: MDPI stays neutral with regard to jurisdictional claims in published maps and institutional affiliations.

Copyright: (C) 2022 by the authors. Licensee MDPI, Basel, Switzerland. This article is an open access article distributed under the terms and conditions of the Creative Commons Attribution (CC BY) license (https:// creativecommons.org/licenses/by/ $4.0 /$ )

\begin{abstract}
Hydrogen peroxide $\left(\mathrm{H}_{2} \mathrm{O}_{2}\right)$ is a key chemical for many industrial applications, yet it is primarily produced by the energy-intensive anthraquinone process. As part of the Power-to-X scenario of electrosynthesis, the controlled oxygen reduction reaction (ORR) can enable the decentralized and renewable production of $\mathrm{H}_{2} \mathrm{O}_{2}$. We have previously demonstrated that self-supported electrocatalytic materials derived from polyaniline by chemical oxidative polymerization have shown promising activity for the reduction of $\mathrm{H}_{2} \mathrm{O}$ to $\mathrm{H}_{2}$ in alkaline media. Herein, we interrogate whether such materials could also catalyze the electro-conversion of $\mathrm{O}_{2}$-to- $\mathrm{H}_{2} \mathrm{O}_{2}$ in an alkaline medium by means of a selective two-electron pathway of ORR. To probe such a hypothesis, nine sets of polyaniline-based materials were synthesized by controlling the polymerization of aniline in the presence or not of nickel (+II) and cobalt (+II), which was followed by thermal treatment under air and inert gas. The selectivity and faradaic efficiency were evaluated by complementary electroanalytical methods of rotating ring-disk electrode (RRDE) and electrolysis combined with spectrophotometry. It was found that the presence of cobalt species inhibits the performance. The selectivity towards $\mathrm{H}_{2} \mathrm{O}_{2}$ was $65-80 \%$ for polyaniline and nickel-modified polyaniline. The production rate was $974 \pm 83,1057 \pm 64$ and

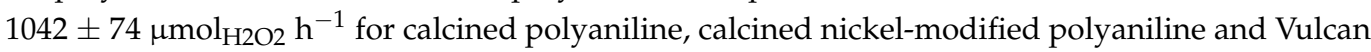
XC 72R (state-of-the-art electrocatalyst), respectively, which corresponds to $487 \pm 42,529 \pm 32$ and $521 \pm 37 \mathrm{~mol} \mathrm{~kg}^{-1} \mathrm{cat}^{-1}\left(122 \pm 10,132 \pm 8\right.$ and $130 \pm 9 \mathrm{~mol} \mathrm{~kg}^{-1}$ cat $\left.\mathrm{cm}^{-2}\right)$ for faradaic efficiencies of $58-78 \%$.
\end{abstract}

Keywords: conducting polymer; polyaniline; electrocatalysis; hydrogen peroxide; oxygen reduction reaction; electrosynthesis

\section{Introduction}

Hydrogen peroxide $\left(\mathrm{H}_{2} \mathrm{O}_{2}\right)$ is one of the most important chemicals in the chemical and medical industries. Its industrial production largely depends on the anthraquinone process, an energy-intensive process that involves the hydrogenation of 2-alkylanthraquinone using expensive palladium catalysts and generates numerous by-products [1,2]. Indeed, to address the high and increasing demand (application for disinfection, textile bleaching, wastewater treatment and renewable energy storage), the four possible methods to produce $\mathrm{H}_{2} \mathrm{O}_{2}$ include the traditional anthraquinone process, direct synthesis, photocatalysis and electrocatalysis [3-5]. As an alternative to the anthraquinone process, the direct reaction $\left(\mathrm{H}_{2}+\mathrm{O}_{2} \rightarrow \mathrm{H}_{2} \mathrm{O}_{2}\right)$ is conceptually the simplest method, but it requires high pressure and finding $\mathrm{H}_{2}$ that is not yet produced in a decarbonized way. The photocatalysis that provides the required energy for the direct method by the solar power is contingent on climatic conditions, so it may not be the sole answer. The electrocatalytic $[3,6-10]$ (or 
even photoelectrocatalytic [11,12]) pathway, the so-called Power-to- $X$ approach, is thus seen as a promising option where electrical energy from any source (ideally renewable) would allow the intelligent and elegant production of hydrogen peroxide from naturally available reactants, either by the partial oxidation of water $\left(2 \mathrm{H}_{2} \mathrm{O} \rightarrow \mathrm{H}_{2} \mathrm{O}_{2}+2 \mathrm{H}^{+}+2 \mathrm{e}^{-}\right)$ or the partial reduction of atmospheric oxygen $\left(\mathrm{O}_{2}+2 \mathrm{H}^{+}+2 \mathrm{e}^{-} \rightarrow \mathrm{H}_{2} \mathrm{O}_{2}\right)$. For that, we need highly selective electrocatalysts to circumvent the four-electron pathway that reduces the faradaic efficiency (portion of the used electrical energy to make a targeted electron transfer reaction).

For environmentally friendly chemistry, the electrocatalytic pathway of reducing $\mathrm{O}_{2}$ from air under alkaline media $\left(\mathrm{O}_{2}+\mathrm{H}_{2} \mathrm{O}+2 \mathrm{e}^{-} \rightarrow \mathrm{HO}_{2}{ }^{-}+\mathrm{HO}^{-}, \mathrm{E}^{\circ}=0.76 \mathrm{~V}\right.$ vs. RHE, reversible hydrogen electrode) at ambient conditions is increasingly being considered, ideally by using noble metal-free electrocatalysts for chemical stability and cost reduction reasons $[13,14]$. To achieve such an alternative, we would need to develop a material that would not push the reduction very far, $\mathrm{O}_{2}+2 \mathrm{H}_{2} \mathrm{O}+4 \mathrm{e}^{-} \rightarrow 4 \mathrm{HO}^{-}, \mathrm{E}^{\circ}=1.23 \mathrm{~V}_{\text {RHE}}$. As reported in Ref. [3], a selectivity of $60-90 \%$ is reported for oxygen-to-hydrogen peroxide using the electroanalytical method of rotating ring-disk electrode (RRDE), which is associated with a faradaic efficiency surpassing $80 \%$ in bulk electrolysis systems (record production rate of $3660 \mathrm{~mol}_{\mathrm{H} 2 \mathrm{O} 2} \mathrm{~kg}_{\mathrm{cat}}{ }^{-1} \mathrm{~cm}^{-2}\left(3.4 \mathrm{mmol}_{\mathrm{H} 2 \mathrm{O} 2} \mathrm{~cm}^{-2} \mathrm{~h}^{-1}\right)$ for a faradaic efficiency of $90 \%$ at a cell voltage of $0.6 \mathrm{~V}$ (current density of $200 \mathrm{~mA} \mathrm{~cm}^{-2}$ ) [8]).

While polyaniline-based materials were used to engineer electrocatalysts for ORR, few studies focused on controlling the selectivity towards the two-electron pathway to produce hydrogen peroxide [15-17]. Rabl et al. [17] found that the electrochemically grown conducting polymers of polyaniline (PANI) and polypyrrole onto carbon paper electrodes can efficiently perform the oxygen-to-hydrogen peroxide electro-conversion in a wide window of $\mathrm{pH}$. Quílez-Bermejo et al. [18] reported PANI-derived N-doped mesoporous carbons for ORR in alkaline media, but the depth of the reaction was not scrutinized to evaluate whether a four-electron pathway was followed or whether hydrogen peroxide is the main product. Our recent and systematic studies $[19,20]$ showed that the synthesis conditions and the post-synthesis thermal treatment of raw PANI under various conditions can produce different types of materials with different electrocatalytic behaviors. However, we currently lack knowledge about the effect of chemical and thermal modifications of PANI on the performance in hydrogen peroxide production of a selective two-electron pathway of ORR. To fill this gap in the knowledge, the aim of the present work is to conduct a case study on the potentiality of oxygen-to-hydrogen peroxide electro-conversion at electrocatalysts made of PANI modified or not by nickel and cobalt species and having undergone or not a thermal treatment. The study was conducted by combining RRDE and bulk electrolysis in alkaline media.

\section{Experimental}

\subsection{Materials and Chemicals}

Potassium hydroxide ( $\mathrm{KOH}, 99.98 \%$ (trace metal basis), Acros Organics), nickel (II) nitrate hexahydrate $\left(\mathrm{Ni}\left(\mathrm{NO}_{3}\right)_{2} \cdot 6 \mathrm{H}_{2} \mathrm{O}, 99 \%\right.$, Acros Organics, Illkirch Cedex, France), hydrochloric acid ( $\mathrm{HCl}, 37 \%$, VWR, Rosny-sous-Bois, France), cobalt (II) nitrate hexahydrate $\left(\mathrm{Co}\left(\mathrm{NO}_{3}\right)_{2} \cdot 6 \mathrm{H}_{2} \mathrm{O}, \mathrm{ACS}, 98.0-102.0 \%\right.$, Alfer Aesar, Havehill, MA, USA), aniline (ANI, $100 \%$, Alfa Aesar), ammonium persulfate ( $\left(\mathrm{NH}_{4}\right)_{2} \mathrm{~S}_{2} \mathrm{O}_{8}, 98 \%$, Merck, Kenilworth, NJ, USA), isopropanol (iPrOH, 99.5\%, Sigma Aldrich, Saint Louis, MO, USA) and Nafion ${ }^{\circledR}$ suspension ( $5 \mathrm{wt} \%$, Sigma Aldrich) were used as received. Commercial carbon black, type Vulcan XC72R, was provided by Cabot Corporation (Europe, Middle East \& Africa; SIA Cabot Latvia, Riga, Latvia) and thermally activated before use by the procedure of Ref. [21]. A carbon paper electrode (AvCarb MGL370, $370 \mu \mathrm{m}$ thickness) was purchased from Fuel Cell Earth LL (USA) and washed with $\mathrm{iPrOH}$ prior to use. Ultrapure water was produced from a Milli-Q Millipore source $\left(18.2 \mathrm{M} \Omega \mathrm{cm}\right.$ at $\left.20^{\circ} \mathrm{C}\right)$. Nitrogen $\left(\mathrm{N}_{2}\right)$ and oxygen $\left(\mathrm{O}_{2}\right)$ were ultrapure (Air Liquide, Paris, France). 


\subsection{Synthesis of Polyaniline-Based Materials by Oxidative Polymerization and Thermal Treatments}

A line up of nine polyaniline-derived materials were prepared by our optimized method of the oxidative polymerization of aniline, triggered by APS in an acidic medium as reported in Ref. [20]. The starting mixture was an acidified $(0.5 \mathrm{M} \mathrm{HCl})$ solution of $0.4 \mathrm{M}$ ANI in the absence and presence of $0.181 \mathrm{M}$ of $\mathrm{Ni}\left(\mathrm{NO}_{3}\right)_{2} \cdot 6 \mathrm{H}_{2} \mathrm{O}$ or $\mathrm{Co}\left(\mathrm{NO}_{3}\right)_{2} \cdot 6 \mathrm{H}_{2} \mathrm{O}$ at $5{ }^{\circ} \mathrm{C}$. This mixture was titrated by an acidified $(0.5 \mathrm{M} \mathrm{HCl})$ solution of APS $(0.2 \mathrm{M}, 100 \mathrm{~mL})$ at five milliliters per minute using a two-syringe infusion pump (KD Scientific, Holliston, MA, USA). After $13 \mathrm{~h}$ of polymerization, the solvent was removed using a rotavap before drying at $80^{\circ} \mathrm{C}$ overnight in an oven to recover a solid polymer product. At this stage, the three materials were referred to as PANI, PANI-Ni and PANI-Co. Next, these materials underwent a thermal stabilization step and/or reticulation of the polymer (TS) under air at $120^{\circ} \mathrm{C} \mathrm{h}^{-1}$ up to an optimized temperature of $350^{\circ} \mathrm{C}$ for $2 \mathrm{~h}$ [20]. The achieved materials are hereinafter termed as PANI-TS, PANI-Ni-ST and PANI-Co-TS. Lastly, the former samples were treated under inert gas $\left(\mathrm{N}_{2}\right)$ at $300{ }^{\circ} \mathrm{C} \mathrm{h}^{-1}$ up to a dwell of $50{ }^{\circ} \mathrm{C}(1 \mathrm{~h})$ and slowed down to $120^{\circ} \mathrm{C} \mathrm{h}^{-1}$ toward the optimized temperature of $900{ }^{\circ} \mathrm{C}$ for $6 \mathrm{~h}$ [20]. The obtained materials were referred to as PANI-TS-TC, PANI-Ni-TS-TC and PANI-Co-TS-TC.

\subsection{Physicochemical Characterization}

We note that the motivation of the present work was to interrogate the electrocatalytic ability of the previous materials that were extensively characterized by XPS, BET, ICP, CNHSO, Raman spectroscopy and FTIRS, as reported in Refs. [19,20]. Herein, we included few characterizations of the nine synthesized samples by scanning electron microscopy (SEM), energy-dispersive X-ray spectroscopy (EDX) and power diffraction X-ray (XRD). SEM was conducted on a Hitachi S-4800 FEG. EDX was performed by using a ZEISS EVOHD 15 microscope. XRD was performed by using a PANalytical Xpert-PRO diffractometer $(40 \mathrm{kV}, 20 \mathrm{~mA})$ equipped with a copper anode $(\lambda(\mathrm{CuK} \alpha)=1.54 \AA)$ in BraggBrentano mode.

\subsection{Electrochemical Measurements, Bulk Electrolysis and UV-Vis Assays}

An AUTOLAB PGSTAT128N bipotentiostat-galvanostat (Metrohm, Barendrecht, Netherlands) equipped with a linear SCAN250 module (Analog scan generator, enables the true linear scan from $10 \mathrm{mV} \mathrm{s}^{-1}$ to $250 \mathrm{kV} \mathrm{s}^{-1}$ ) was used for the electrochemical measurements. The used methods were cyclic voltammetry (CV), linear sweep voltammetry (LSV) and chronoamperometry (CA). RRDE setup (Metrohm, Netherlands) was composed of a glassy carbon disk (5 mm diameter, $\left.0.196 \mathrm{~cm}^{2}\right)$ and a Pt ring $\left(0.072 \mathrm{~cm}^{2}\right)$. RRDE was manually polished by alumina slurries of increasing particles size $(3,1$ and $0.05 \mu \mathrm{m})$ and washed with ultrapure water by sonication. At the same time, a catalytic ink was prepared by ultrasonically mixing (water batch) $130 \mu \mathrm{L}$ of ultrapure water, $50 \mu \mathrm{L}$ of isopropanol, $20 \mu \mathrm{L}$ of Nafion ${ }^{\circledR}$ suspension and $5 \mathrm{mg}$ of electrocatalyst. After drying the RRDE, a volume of $4 \mu \mathrm{L}$ was deposited onto the disk to yield $0.5 \mathrm{mg}_{\mathrm{cat}} \mathrm{cm}^{-2}$. Then, the rotator speed was increased to $400 \mathrm{rpm}$ to not only facilitate the solvents evaporation under ambient conditions, but also to obtain an homogeneous thin-film of the catalytic layer and repeatable/reproducible experiments [22-25]. After degassing the electrolyte (1 M KOH solution) by $\mathrm{N}_{2}$ for $20 \mathrm{~min}$, the $\mathrm{CV}$ of the blank was recorded in a three-electrode setup where the working electrode was the RRDE disk, the counter electrode was a large surface-area glassy carbon plate and the reference electrode was $\mathrm{Ag} / \mathrm{AgCl}$ (calibrated versus $\mathrm{RHE}$ in $\mathrm{H}_{2}$-saturated electrolyte: $\mathrm{E}_{\mathrm{RHE}}-\mathrm{E}_{\mathrm{Ag} / \mathrm{AgCl}}=0.964 \mathrm{~V}$ ). For ORR, the electrolyte was saturated by $\mathrm{O}_{2}$ for $20 \mathrm{~min}$ and the potential of the disk was scanned in the cathodic direction from the open circuit potential (OCP) to $0.1 \mathrm{~V}_{\mathrm{RHE}}$. The potential of the RRDE ring was poised at $\mathrm{E}_{\text {ring }}=1.2 \mathrm{~V}_{\mathrm{RHE}}$ to oxidize any hydrogen peroxide product from ORR back to $\mathrm{O}_{2}$ and lead to a quantitative metric by the ratio of between the ring current and that of the disk, $\mathrm{I}_{\mathrm{D}} / \mathrm{I}_{\mathrm{R}}$. We note that the predominant form is hydroperoxide anion $\mathrm{HO}_{2}{ }^{-}$because of the electrolyte's $\mathrm{pH}$ of $\sim 14$ and $\mathrm{pKa}\left(\mathrm{H}_{2} \mathrm{O}_{2} / \mathrm{HO}_{2}{ }^{-}\right)=11.75$. 
The quantitative analysis by bulk electrolysis and UV-vis assays were described in Ref. [9]. Typically, the two compartments of a H-type cell were separated by a hydroxide anion exchange membrane and each contained $60 \mathrm{~mL}$ of $1 \mathrm{M} \mathrm{KOH}$ at room temperature $\left(22 \pm 2{ }^{\circ} \mathrm{C}\right)$. The cathodic compartment saturated by $\mathrm{O}_{2}$ held a carbon paper electrode (AvCarb MGL370, $370 \mu \mathrm{m}$ thickness, $1 \mathrm{~cm} \times 2 \mathrm{~cm}$ ) coated with the above catalytic ink at $0.5 \mathrm{mg}_{\text {cat }} \mathrm{cm}^{-2}$ (both sides), and its potential was poised at $0.6 \mathrm{~V}_{\mathrm{RHE}}$ (iR-uncorrected) for $1 \mathrm{~h}$. Aliquots were sequentially taken for UV-vis assays using the UviLine Connect 940 spectrophotometer (Spectralab software). Each solution was treated with an equivalent excess of $\mathrm{H}_{2} \mathrm{SO}_{4}$ (at $0.34 \mathrm{~mol}$ per $\mathrm{L}$ to generate $\mathrm{H}_{2} \mathrm{O}_{2}$ species: $\mathrm{HO}_{2}{ }^{-}$(aq) $+\mathrm{H}^{+}{ }_{(\mathrm{aq})} \rightarrow \mathrm{H}_{2} \mathrm{O}_{2}$, $\mathrm{pKa}=11.75$ ) and potassium titanium (IV) oxalate (at $50 \mathrm{~g}$ per L to form a colored indicator with $\mathrm{H}_{2} \mathrm{O}_{2}$ ). After preliminary tests in a full spectrum configuration (300-900 nm), the absorbance of the yellow pertitanic acid complex between hydrogen peroxide and potassium titanium oxalate was measured at $390 \mathrm{~nm}[9,26-29]$ in the kinetic configuration.

\section{Results and Discussion}

\subsection{Electrochemical Analysis}

To better understand the electrochemical behaviors of the nine synthesized materials, the $\mathrm{CV}$ of each electrode was recorded in $\mathrm{N}_{2}$-saturated $1 \mathrm{M} \mathrm{KOH}$ at $25^{\circ} \mathrm{C}$ and $100 \mathrm{mV} \mathrm{s}^{-1}$ $(0 \mathrm{rpm})$. We chose not to apply ohmic drop correction, even though the ohmic resistance was in the range of 5-6 $\Omega$ as determined by the electrochemical impedance spectroscopy (EIS), indicating an ohmic drop in potential of $25-30 \mathrm{mV}$ at an absolute current of $5 \mathrm{~mA}$. Figure 1a shows the blank CV profiles for the three materials after the oxidative chemical polymerization. Compared to acidic media where characteristic redox processes for the oxidation states of PANI can be observed [19,30], in the alkaline environment, there is no major oxidation or reduction peak of electron transfer. When the polymerization was conducted in the presence of nickel or cobalt species $\left(\mathrm{Ni}^{2+}\right.$ and $\left.\mathrm{Co}^{2+}\right)$, the redox processes associated with the oxy-hydroxide transitions can be observed between $1.0 \mathrm{~V}_{\mathrm{RHE}}$ and $1.5 \mathrm{~V}_{\mathrm{RHE}}\left[\mathrm{M}(\mathrm{OH})_{2}+\mathrm{OH}^{-}=\mathrm{MOOH}+\mathrm{H}_{2} \mathrm{O}+\mathrm{e}^{-}, \mathrm{M}=\mathrm{Ni}, \mathrm{Co}\right]$.

We next used the electroanalytical method of the electrochemical double-layer capacitance to determine whether the introduced $\mathrm{Ni}(+\mathrm{II})$ and $\mathrm{Co}(+\mathrm{II})$ species modified the electrochemically active surface area (ECSA) according to the relationship ECSA $=\mathrm{C}_{\mathrm{dl}} / \mathrm{C}_{\mathrm{s}}$, where $C_{d l}$ is the capacitance and $C_{s}$ is the average specific capacitance (about $40 \mu \mathrm{F} \mathrm{cm}{ }^{-2}$ ) [31,32]. To this end, the voltammograms were recorded in the capacitive region at different scan rates. Figure $2 \mathrm{~b}$ shows the results for PANI, while those of PANI-Ni and PANI-Co are reported in Figure S2. The plots of the capacitive current $\left(\Delta \mathrm{I}_{\mathrm{a}}=\mathrm{I}_{\mathrm{a}}-\mathrm{I}_{\mathrm{c}}\right)$ versus the scan rate at a given electrode potential $\left(\mathrm{E}\left(\mathrm{V}_{\mathrm{RHE}}\right)=0.8,1.0\right.$ and 0.8 for PANI, PANI-Ni and PANI-Co, respectively) display a linear trend where the slope is twice the capacitance. The trend is PANI-NI $\left(\mathrm{C}_{\mathrm{dl}}=63 \pm 1 \mu \mathrm{F}\right)<$ PANI $\left(\mathrm{C}_{\mathrm{dl}}=75 \pm 1 \mu \mathrm{F}\right)<$ PANI-Co $\left(\mathrm{C}_{\mathrm{dl}}=91 \pm 2 \mu \mathrm{F}\right)$, which indicates a modification in the number of the available electrochemical active sites. The next question is whether all these active sites are in favor of a better hydrogen peroxide production by selective $\mathrm{O}_{2}$ reduction. It is known that the selectivity toward hydrogen peroxide production requires $\mathrm{O}_{2}$ molecules to be perpendicularly adsorbed by a single oxygen atom on the catalytic surface (a parallel adsorption will trigger the oxygen-oxygen bond cleavage), which can be achieved by tuning the inter-distance between active sites and the heterogeneity of the catalytic surface [9,33-35]. In the following, we will briefly explain the basics of the used electroanalytical method to track the depth of the ORR on-line.

During ORR in alkaline media, $\mathrm{O}_{2}$ molecule can receive either four or two electrons to produce $\mathrm{OH}^{-}$according to the net Equation (1) or to yield $\mathrm{HO}_{2}{ }^{-}$according to Equation (2). The produced hydroperoxide anion can then be reduced into $\mathrm{OH}^{-}$according to Equation (3) or be stable as the final product. For the latter case, it can be oxidized at the ring of an RRDE setup [36]. Hence, by employing a RRDE setup [36,37], it is possible to derive electroanalytical relationships that link the transferred number of electrons per molecule of $\mathrm{O}_{2}\left(\mathrm{n}_{\mathrm{ex}}\right)$ and the amount of hydrogen peroxide to the current of the disk $\left(\mathrm{I}_{\mathrm{D}}\right)$, the current of the ring $\left(\mathrm{I}_{\mathrm{R}}\right)$ and the collection efficiency $(\mathrm{N}$ : defined as the fraction of the species 
formed at the disk that arrive at the ring and react there [36]). Because the value of the collection efficiency is specific to the geometry of the RRDE and does not depend on the studied redox reaction, we have determined it by employing the simple redox probe $\left[\mathrm{Fe}\left((\mathrm{CN})_{6}\right]^{3-} /\left[\mathrm{Fe}(\mathrm{CN})_{6}\right]^{4-}\right.$ using a four-electrode potentiostat where both potentials of the disk and the ring are controlled with respect to the reference electrode independently. The results are reported in Figure S1 and give an average collection efficiency of $24.9 \pm 0.3 \%$, which is in line with the manufacturer's value of $24.9 \%$.
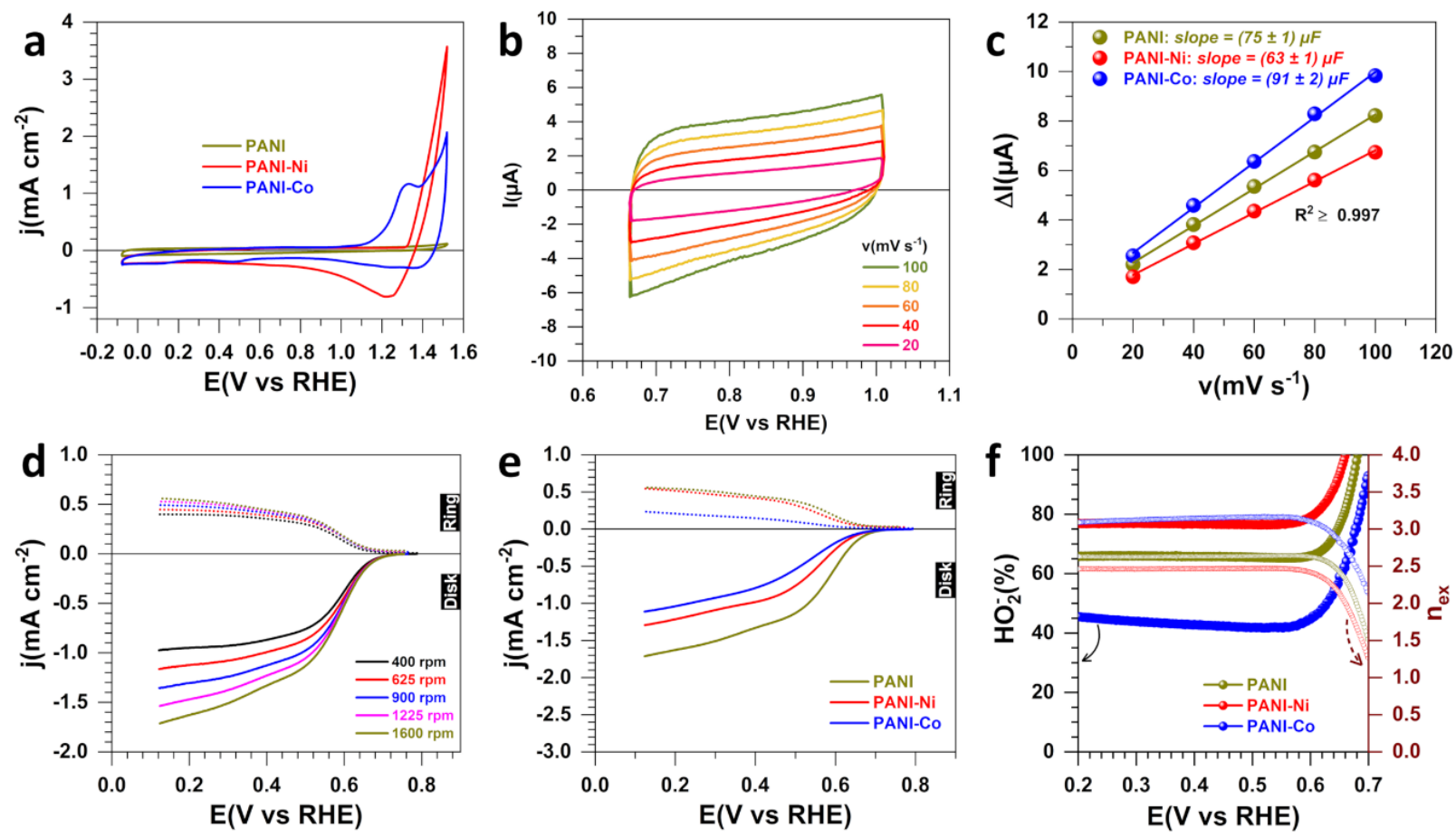

Figure 1. Electrochemical characterization for the materials obtained after polymerization $\left(5{ }^{\circ} \mathrm{C}\right.$, $13 \mathrm{~h}$ ). (a) iR-drop uncorrected $\mathrm{CV}\left(\mathrm{N}_{2}\right.$-saturated $\left.1 \mathrm{M} \mathrm{KOH}, 25^{\circ} \mathrm{C}, 100 \mathrm{mV} \mathrm{s}^{-1}, 0 \mathrm{rpm}\right)$. (b) iRdrop uncorrected $\mathrm{CV}$ of PANI-Ni $\left(\mathrm{N}_{2}\right.$-saturated $\left.1 \mathrm{M} \mathrm{KOH}, 25^{\circ} \mathrm{C}, 0 \mathrm{rpm}\right)$ for determining ECSA. (c) Capacitive current $\left(\Delta \mathrm{I}_{\mathrm{a}}=\mathrm{I}_{\mathrm{a}}-\mathrm{I}_{\mathrm{c}}\right)$ vs. scan rate at $\mathrm{E}\left(\mathrm{V}_{\mathrm{RHE}}\right)=0.8$ (PANI), 1.0 (PANI-Ni) and 0.8 (PANI-Co). (d) iR-drop uncorrected LSV of ORR for PANI at different speeds of RRDE $\left(\mathrm{O}_{2}\right.$-saturated $1 \mathrm{M} \mathrm{KOH}, 25^{\circ} \mathrm{C}, 5 \mathrm{mV} \mathrm{s}^{-1}$, $\left.\mathrm{E}_{\text {ring }}=1.2 \mathrm{~V}_{\mathrm{RHE}}\right)$. (e) iR-drop uncorrected LSV of ORR at $\operatorname{RRDE}\left(\mathrm{O}_{2}\right.$-saturated $\left.1 \mathrm{M} \mathrm{KOH}, 25^{\circ} \mathrm{C}, 5 \mathrm{mV} \mathrm{s}^{-1}, 1600 \mathrm{rpm}, \mathrm{E}_{\text {ring }}=1.2 \mathrm{~V}_{\mathrm{RHE}}\right)$. (f) $\mathrm{HO}_{2}{ }^{-\%}$ (left) and number of transferred electrons per molecule of $\mathrm{O}_{2}$ (right $y$-axis) from panel (e).

$$
\begin{gathered}
\mathrm{O}_{2}+2 \mathrm{H}_{2} \mathrm{O}+4 \mathrm{e}^{-} \rightarrow 4 \mathrm{HO}^{-} \\
\mathrm{O}_{2}+\mathrm{H}_{2} \mathrm{O}+2 \mathrm{e}^{-} \rightarrow \mathrm{HO}_{2}^{-}+\mathrm{HO}^{-} \\
\mathrm{HO}_{2}{ }^{-}+\mathrm{H}_{2} \mathrm{O}+2 \mathrm{e}^{-} \rightarrow 3 \mathrm{HO}^{-}
\end{gathered}
$$

Let $\mathrm{I}_{1}, \mathrm{I}_{2}$, and $\mathrm{I}_{3}$ be the currents corresponding to these three electrochemical processes of ORR at the disk of $\operatorname{RRDE}\left(\mathrm{I}_{\mathrm{D}}=\mathrm{I}_{1}+\mathrm{I}_{2}+\mathrm{I}_{3}\right) . \mathrm{I}_{1}, \mathrm{I}_{2}$ and $\mathrm{I}_{3}$ have the same sign (counted either as positive or negative depending on the used convention to plot the current-potential curves [38]), meaning that mathematic rules do apply. According to the second law of Faraday, the total number of $\mathrm{O}_{2}$ molecules participating in ORR is given by Equation (4) below.

$$
N\left(\mathrm{O}_{2}\right)=\left[\left(n\left(\mathrm{O}_{2}\right)\right)_{\text {involved in } 4 \text {-electron process }}+\left(n\left(\mathrm{O}_{2}\right)\right)_{\text {involved in 2-electron process }}\right] N_{A}=\left|I_{1}+2 I_{2}\right| \frac{t N_{A}}{4 F}
$$

In Equation (4), $t=$ duration, $N_{A}=$ Avogadro constant, $F=$ Faraday constant, and $|I|=\mathrm{ab}-$ solute value of the current. By taking into account the conservation of matter (Lavoisier), 
the total transferred number of electrons and the total number of produced hydroperoxide anion $\mathrm{HO}_{2}{ }^{-}$molecules can be readily evaluated by Equations (5) and (6), respectively.

$$
\begin{aligned}
& N\left(e^{-}\right)=\left|I_{1}+I_{2}+I_{3}\right| \frac{t N_{A}}{F} \\
& N\left(H O_{2}^{-}\right)=\left[\left(n\left(H O_{2}^{-}\right)\right)_{\text {involved in Eq. S2 }}-\left(n\left(H O_{2}^{-}\right)\right)_{\text {involved in Eq. S3 }}\right] N_{A}=\left|I_{2}-I_{3}\right| \frac{t N_{A}}{2 F} \\
& N=\left|\frac{I_{R}}{\left(I_{D, \text { total }}\right)_{\text {involving } \mathrm{HO}_{2}^{-} \text {species }}}\right|=\left|\frac{I_{R}}{I_{2}-I_{3}}\right| \Rightarrow\left|I_{R}\right|=\left|I_{2}-I_{3}\right| N \\
& n_{e x}=\frac{N\left(e^{-}\right)}{N\left(O_{2}\right)}=4 \frac{I_{1}+I_{2}+I_{3}}{I_{1}+2 I_{2}}=4 \frac{\left|I_{1}+I_{2}+I_{3}\right|}{\left|I_{1}+I_{2}+I_{3}\right|+\left|I_{2}-I_{3}\right|}=4 \frac{1}{1+\left|\frac{I_{R}}{N I_{D}}\right|}=\frac{4}{1-\frac{I_{R}}{N I_{D}}} \\
& H O_{2}^{-}(\%)=100 \frac{N\left(H O_{2}^{-}\right)}{N\left(O_{2}\right)}=200 \frac{\left|I_{2}-I_{3}\right|}{\left|I_{1}+2 I_{2}\right|}=200 \frac{\left|I_{2}-I_{3}\right|}{\left|I_{1}+I_{2}+I_{3}\right|+\left|I_{2}-I_{3}\right|}=\frac{200}{1-\frac{N I_{D}}{I_{R}}}
\end{aligned}
$$

We note that $I_{D}$ and $I_{R}$ have opposite signs ( $I_{D}$ is counted either as positive or negative depending on the used convention to plot the current-potential curves [38]). Therefore, the ratio $I_{D} / I_{R}$ is algebraically a negative number, which justifies the sign (-) in the absence of the absolute value to avoid the frequently made mistake in the literature where people use the sign (+). Figure 1d shows the representative current-potential profiles of the disk and the ring at different speeds of RRDE for PANI. The corresponding percentage of $\mathrm{HO}_{2}{ }^{-}$and the number of transferred electrons per molecule of $\mathrm{O}_{2}$ from this iR-drop uncorrected LSV of ORR are reported in Figure S3. For the three materials obtained from the polymerization step, the comparison at $1600 \mathrm{rpm}$ is shown in Figure 1e for LSV and in Figure $1 \mathrm{f}$ for $\mathrm{HO}_{2}{ }^{-}$, along with the number of transferred electrons per molecule of $\mathrm{O}_{2}$. The LSV shows that ORR starts at a potential close to the expected potential for the process $\mathrm{O}_{2}+\mathrm{H}_{2} \mathrm{O}+2 \mathrm{e}^{-} \rightarrow \mathrm{HO}_{2}{ }^{-}+\mathrm{HO}^{-}, \mathrm{E}^{\circ}=0.76 \mathrm{~V}_{\mathrm{RHE}}$. It is worth noting, however, that this could also correspond to the other process with four electrons $\left(\mathrm{O}_{2}+2 \mathrm{H}_{2} \mathrm{O}+4 \mathrm{e}^{-} \rightarrow 4 \mathrm{HO}^{-}\right.$, $\mathrm{E}^{\circ}=1.23 \mathrm{~V}_{\mathrm{RHE}}$ ). Indeed, the starting potential in the case of ORR is not a fair descriptor because ORR has slow kinetics and not all of the species of the redox couple $\mathrm{O}_{2} / \mathrm{HO}_{2}{ }^{-}$ are present in the beginning to satisfy the condition of Nernst thermodynamics. Only quantitative analysis can provide insightful information.

While the amount of $\mathrm{HO}_{2}{ }^{-}$and the total transferred electrons per molecule of $\mathrm{O}_{2}\left(n_{\mathrm{ex}}\right)$ were evaluated online by Equations (8) and (9), the Levich relationship of Equation (10) can be used to evaluate $n_{\mathrm{ex}}[37,39]$ when the plateau for limiting current density is well-defined. We note that the validity of Levich's law is subject to the following two requirements:

(i) The existence of a mass transport process that is the rate-determining step (rds),

(ii) The reaction is of a first order reaction with respect to the electroreactive species $\left(\mathrm{O}_{2}\right)$.

The kinetic current density $j_{\mathrm{k}}$ as the absolute activity can be derived from Equation (11) before the conversion into the mass activity $j_{\mathrm{k}}\left(\mathrm{A} \mathrm{mg}^{-1}\right)$ by the division of the absolute value by the electrocatalyst loading $\left(\mathrm{mg}_{\mathrm{cat}} \mathrm{cm}^{-2}\right.$ geometric $)$ or specific kinetic current density $j_{\mathrm{k}}\left(\mathrm{mA} \mathrm{cm}^{-2} \mathrm{ECSA}\right)[36,37]$.

$$
\begin{gathered}
j_{\lim }=n_{e x} \times B \times \Omega^{\frac{1}{2}}, \quad B=0.201 F C v^{-\frac{1}{6}} D^{\frac{2}{3}} \\
\frac{1}{j}=\frac{1}{j_{\lim }}+\frac{1}{j_{k}} \Rightarrow j_{k}=\frac{j \times j_{\lim }}{j_{\lim }-j}
\end{gathered}
$$


$j$ : current density of the disk (geometric). $j_{\text {lim }}$ : diffusion-limiting current density of the plateau (geometric), $\mathrm{O}_{2}$ mass transport limitation in electrolyte. $n_{e x}$ : overall passed number of electrons per molecule of $\mathrm{O}_{2}$. F: Faraday constant $\left(F=96485 \mathrm{C} \mathrm{mol}^{-1}\right)$. $D$ : diffusion coefficient of $\mathrm{O}_{2}$ in the electrolyte $\left(D=1.8 \times 10^{-5} \mathrm{~cm}^{2} \mathrm{~s}^{-1}\right.$ in $\left.1 \mathrm{M} \mathrm{KOH}\right)$. $\Omega$ : speed of RRDE (rpm). $C$ : $\mathrm{O}_{2}$ concentration in the electrolyte $\left(C=7.8 \times 10^{-4} \mathrm{~mol} \mathrm{~cm}^{-3}\right.$ in $1 \mathrm{M} \mathrm{KOH})$. $v$ : kinematic viscosity of the electrolyte $\left(v=1.0 \times 10^{-2} \mathrm{~cm}^{2} \mathrm{~s}^{-1}\right.$ in $\left.1 \mathrm{M} \mathrm{KOH}\right)$. $j_{k}$ : mass-corrected kinetic current density (absolute activity). If the disk current is $\mathrm{I}_{\mathrm{D}}(\mathrm{A})$, then $C\left(\mathrm{~mol} \mathrm{~cm}^{-3}\right)$; if the disk current is $\mathrm{I}_{\mathrm{D}}(\mathrm{mA})$, then $C\left(\mathrm{~mol} \mathrm{dm}^{-3} \equiv \mathrm{mol} \mathrm{L}^{-1}\right)$.

In $1 \mathrm{M} \mathrm{KOH}$ at $1600 \mathrm{rpm}$, the calculated diffusion-limiting current density of ORR is 3.6 and $1.8 \mathrm{~mA} \mathrm{~cm}^{-2}$ for $n_{e x}=4$ (complete reduction) and $n_{e x}=2$ (expected partial reduction), respectively. Figure 1e shows that the current density at low potentials is especially small for the material PANI-Co, which suggests a reduced electrocatalytic activity in driving high current density even though this material displays the highest electrochemically active surface area (Figure 1c). From Figure 1f, the trend in hydrogen peroxide selectivity is PANI-Co < PANI < PANI-Ni. Specifically, at $0.6 \mathrm{~V}_{\mathrm{RHE}}, \mathrm{HO}_{2}{ }^{-}(\%)$ is 40,75 and 65 for PANI, PANI-Ni and PANI-Co, respectively. Taken together, the results indicate that the augmentation of the number of the available electrochemical active sites does not directly translate into a high performance in hydrogen peroxide production. It can be assumed that the presence of nickel cations significantly increases the selectivity in hydrogen peroxide production. However, this remains a proof of concept without real applications, since such an electrocatalyst cannot be stable in aqueous media, as the metal cation would leave in the electrolyte during long-term application. Therefore, a stabilization step by thermal treatment is necessary to obtain a stable electrocatalyst. For this reason, we investigated the same three materials having undergone a first heat treatment under air-in this case study, the temperature of $350{ }^{\circ} \mathrm{C}$ was considered (on the basis of our previous study [20]).

Figure 2a-d show the obtained results for the three materials after the polymerization $\left(5{ }^{\circ} \mathrm{C}, 13 \mathrm{~h}\right.$ ) and the stabilization (air, $350{ }^{\circ} \mathrm{C}, 2 \mathrm{~h}$ ), PANI-TS, PANI-Ni-TS and PANI-Co-TS. Extended data are reported in Figure S4 for the double-layer capacitance measurements for determining the electrochemically active surface area (ECSA). Figure 2a shows a change in the $\mathrm{CV}$ profiles for PANI-Co, possibly because of the oxidation that suppresses the redox processes associated with the oxy-hydroxide transitions of $\mathrm{M}(\mathrm{OH})_{2}+\mathrm{OH}^{-}=\mathrm{MOOH}+$ $\mathrm{H}_{2} \mathrm{O}+\mathrm{e}^{-}(\mathrm{M}=\mathrm{Ni}, \mathrm{Co})$, still present for the material PANI-Ni when considering the intensity of the peak at $1.25 \mathrm{~V}_{\mathrm{RHE}}$ [40]. Figure $2 \mathrm{~d}$ shows that the capacitance increases after this thermal treatment where the ECSA trend is PANI-NI $\left(\mathrm{C}_{\mathrm{dl}}=77 \pm 3 \mu \mathrm{F}\right)<$ PANI $\left(\mathrm{C}_{\mathrm{dl}}=92 \pm 2 \mu \mathrm{F}\right)<$ PANI-Co $\left(\mathrm{C}_{\mathrm{dl}}=104 \pm 3 \mu \mathrm{F}\right)$. For ORR, the difference in the LSV at $1600 \mathrm{rpm}$ in $\mathrm{O}_{2}$-saturated $1 \mathrm{M} \mathrm{KOH}$ electrolyte (Figure 2c) is less important compared to the previous situation (Figure 1e). The hydrogen peroxide amount is nearly the same for PANI-Co, $0.6 \mathrm{~V}_{\mathrm{RHE}}, \mathrm{HO}_{2}{ }^{-}(\%) \sim 40$. For PANI-TS and PANI-Ni-TS, there is an inversion of the trend with $\mathrm{HO}_{2}{ }^{-}(\%)$ of $\sim 77$ and 65 at $0.6 \mathrm{~V}_{\mathrm{RHE}}$, respectively. According to our previous XPS analysis, at this stage, the introduced metallic species are at their oxidized state [20]. Hence, it is interesting the examine whether the formation of real metallic species could change the trends in selectivity during ORR. Indeed, we recently showed that using thermal treatment under an inert atmosphere to generate a reductive environment will lead to the formation of mixture of metals and chalcogenides of $\mathrm{NiS}_{x}(x=0,2 / 3,8 / 9$ and $4 / 3)$ or $\operatorname{CoS}_{x}$ $(x=0$ and $8 / 9)$ onto a carbon-nitrogen-sulfur nanostructured network [41].

We next interrogated the impact of the three steps of polymerization $\left(5^{\circ} \mathrm{C}, 13 \mathrm{~h}\right)$, stabilization (air, $350{ }^{\circ} \mathrm{C}, 2 \mathrm{~h}$ ) and calcination $\left(\mathrm{N}_{2}, 900{ }^{\circ} \mathrm{C}, 6 \mathrm{~h}\right.$ ) on the electrochemical properties of ORR in $1 \mathrm{M} \mathrm{KOH}$. The three materials are PANI-TS-TC, PANI-Ni-TS-TC and PANI-Co-TS-TC. To provide a fair comparison, a commercial carbon black, Vulcan $\mathrm{XC72R}$, known for its ability in hydrogen peroxide production was used as a benchmark system. Figure $3 \mathrm{a}-\mathrm{f}$ display the obtained results, while extended data are reported in Figures S5-S8. The overlay voltammograms in Figure 3a confirm the presence of the redox processes associated with the oxy-hydroxide transitions of $\mathrm{Ni}(\mathrm{OH})_{2}+\mathrm{OH}^{-}=\mathrm{NiOOH}+$ $\mathrm{H}_{2} \mathrm{O}+\mathrm{e}^{-}$. The determined double-layer capacitance, proportional to the electrochemically 
active surface area, is $C_{\mathrm{dl}}=4640 \pm 5,3811 \pm 10,230 \pm 4$ and $4002 \pm 19 \mu \mathrm{F}$ for PANITS-TC, PANI-Ni-TS-TC, PANI-Co-TS-TC and Vulcan, respectively. Except for the case of PANI-Co-TS-TC, this calcination dramatically increases the electrochemically active surface area by more than 10 times. The LSV curves in Figure $3 \mathrm{c}$ for ORR at PANI-TS-TC (other materials are reported in Figures S7 and S8) show a well-defined diffusion-limiting current of $2.2 \mathrm{~mA} \mathrm{~cm}^{-2}$ at $1600 \mathrm{rpm}$, which falls between $3.6 \mathrm{~mA} \mathrm{~cm}^{-2}$ for $\mathrm{n}_{\mathrm{ex}}=4$ (complete reduction) and $1.8 \mathrm{~mA} \mathrm{~cm}{ }^{-2}$ for $\mathrm{n}_{\mathrm{ex}}=2$ (expected partial reduction). Furthermore, the overlay current-potential curves of Figure 3e show that the onset potential is close to the theoretically expected $0.75 \mathrm{~V}_{\mathrm{RHE}}$ for the two-electron transferred process. We note that the PANI-Co-TS-TC material presents a linear profile, suggesting that it would present a large ohmic drop resistance, which is not the case, as the found value of $6 \Omega$ will not noticeably change the trend after applying the iR-drop correction, considering the current rage of milliamps.
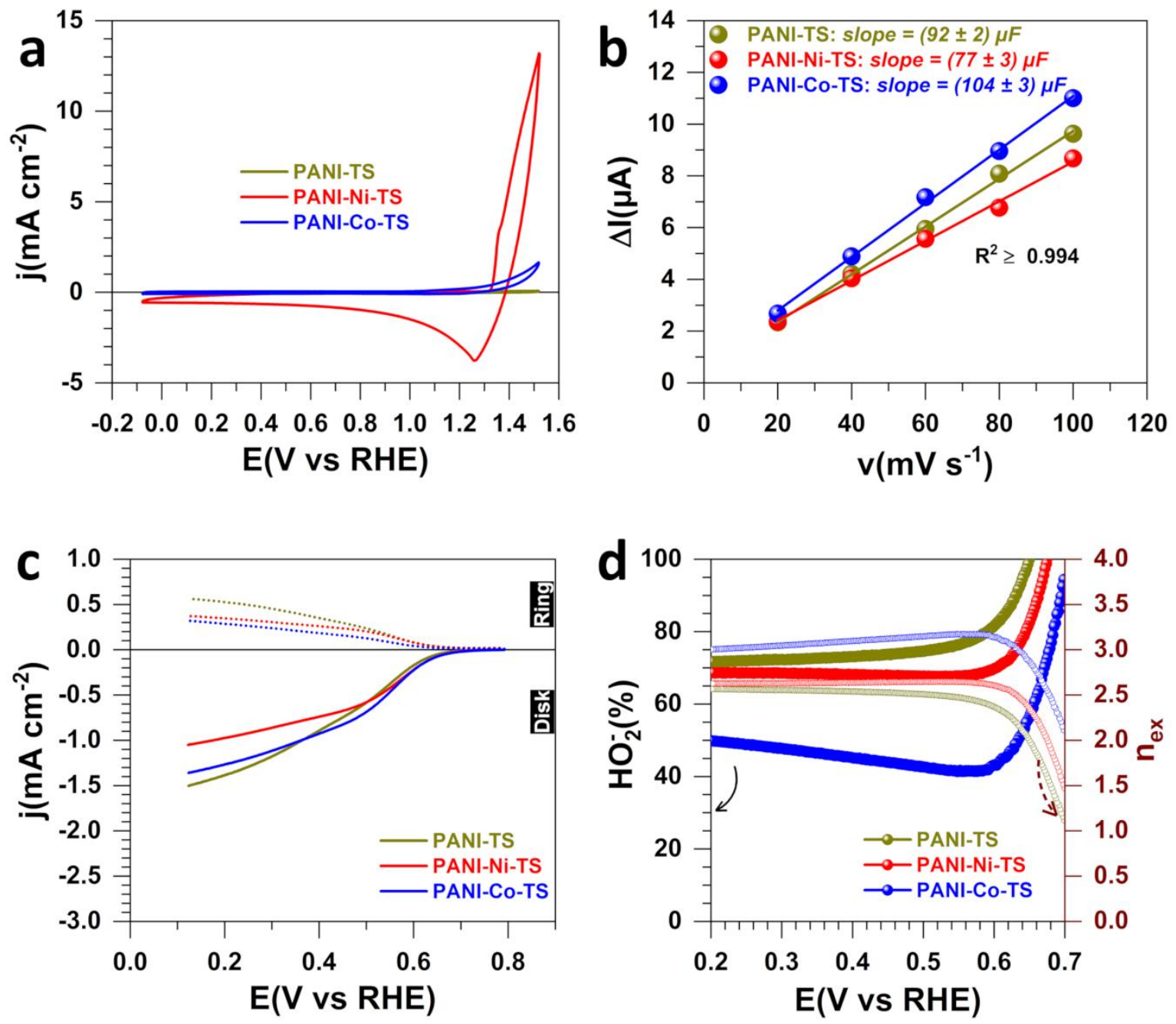

Figure 2. Electrochemical characterization for the materials obtained after polymerization $\left(5{ }^{\circ} \mathrm{C}\right.$, $13 \mathrm{~h}$ ) and stabilization (air, $350^{\circ} \mathrm{C}, 2 \mathrm{~h}$ ). (a) iR-drop uncorrected $\mathrm{CV}\left(\mathrm{N}_{2}\right.$-saturated $1 \mathrm{M} \mathrm{KOH}, 25^{\circ} \mathrm{C}$, $\left.100 \mathrm{mV} \mathrm{s}^{-1}, 0 \mathrm{rpm}\right)$. (b) Capacitive current $\left(\Delta \mathrm{I}_{\mathrm{a}}=\mathrm{I}_{\mathrm{a}}-\mathrm{I}_{\mathrm{C}}\right)$ vs. scan rate at $\mathrm{E}\left(\mathrm{V}_{\mathrm{RHE}}\right)=0.8$ (PANI-TS), 1.2 (PANI-Ni-TS) and 0.7 (PANI-Co-TS). (c) iR-drop uncorrected LSV of ORR at RRDE $\left(\mathrm{O}_{2}\right.$-saturated $1 \mathrm{M} \mathrm{KOH}, 25^{\circ} \mathrm{C}, 5 \mathrm{mV} \mathrm{s}^{-1}, 1600 \mathrm{rpm}, \mathrm{E}_{\text {ring }}=1.2 \mathrm{~V}_{\mathrm{RHE}}$ ). (d) $\mathrm{HO}_{2}{ }^{-\%}$ (left) and number of transferred electrons per molecule of $\mathrm{O}_{2}$ (right $y$-axis) from panel (c). 

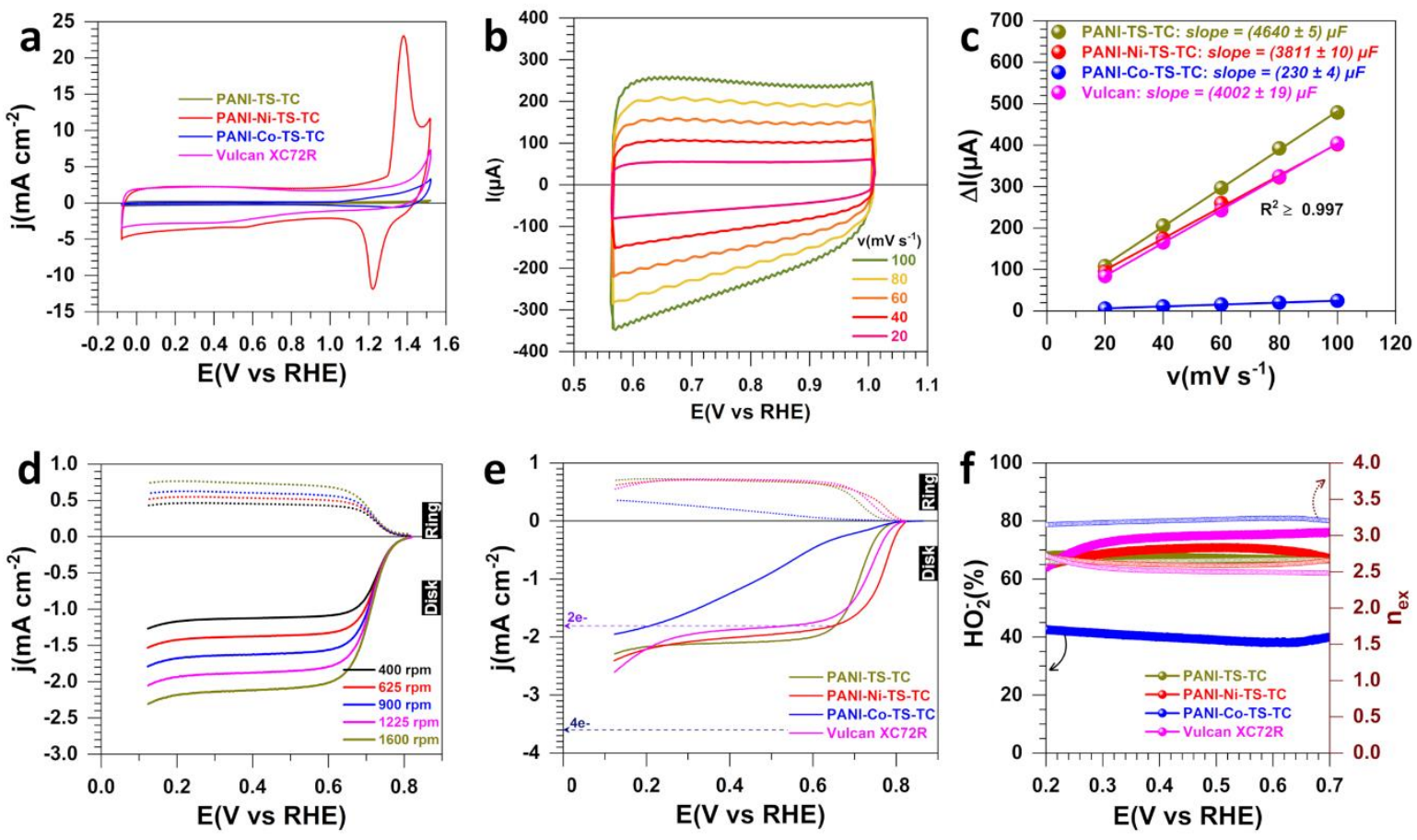

Figure 3. Electrochemical characterization for the materials obtained after polymerization $\left(5{ }^{\circ} \mathrm{C}\right.$, $13 \mathrm{~h}$ ), stabilization (air, $350{ }^{\circ} \mathrm{C}, 2 \mathrm{~h}$ ) and calcination $\left(\mathrm{N}_{2}, 900{ }^{\circ} \mathrm{C}, 6 \mathrm{~h}\right.$ ). (a) iR-drop uncorrected $\mathrm{CV}$ $\left(\mathrm{N}_{2}\right.$-saturated $\left.1 \mathrm{M} \mathrm{KOH}, 25^{\circ} \mathrm{C}, 100 \mathrm{mV} \mathrm{s}^{-1}, 0 \mathrm{rpm}\right)$. (b) iR-drop uncorrected CV of PANI-TS-TC $\left(\mathrm{N}_{2}\right.$-saturated $\left.1 \mathrm{M} \mathrm{KOH}, 25^{\circ} \mathrm{C}, 0 \mathrm{rpm}\right)$ for determining ECSA. (c) Capacitive current $\left(\Delta \mathrm{I}_{\mathrm{a}}=\mathrm{I}_{\mathrm{a}}-\mathrm{I}_{\mathrm{c}}\right)$ vs. scan rate at $\mathrm{E}\left(\mathrm{V}_{\mathrm{RHE}}\right)=0.8$ (PANI-TS-TC), 0.9 (PANI-Ni-TS-TC), 0.7 (PANI-Co-TS-TC) and 1.0 (Vulcan). (d) iR-drop uncorrected LSV of ORR for PANI-TS-TC at different speeds of RRDE $\left(\mathrm{O}_{2}\right.$-saturated $1 \mathrm{M}$ $\left.\mathrm{KOH}, 25^{\circ} \mathrm{C}, 5 \mathrm{mV} \mathrm{s}^{-1}, \mathrm{E}_{\text {ring }}=1.2 \mathrm{~V}_{\mathrm{RHE}}\right)$. (e) iR-drop uncorrected LSV of ORR at RRDE $\left(\mathrm{O}_{2}\right.$-saturated $1 \mathrm{M} \mathrm{KOH}, 25^{\circ} \mathrm{C}, 5 \mathrm{mV} \mathrm{s}^{-1}, 1600 \mathrm{rpm}, \mathrm{E}_{\text {ring }}=1.2 \mathrm{~V}_{\mathrm{RHE}}$ ). (f) $\mathrm{HO}_{2}{ }^{-\%}$ (left) and number of transferred electrons per molecule of $\mathrm{O}_{2}$ (right $y$-axis) from panel (e).

Figure $3 \mathrm{f}$ shows the quantitative analysis from the recorded LSV curves to concurrently visualize the current coming from the oxygen reduction and the ring current following the oxidation any produced hydrogen peroxide. At PANI-Co-TS-TC, $\mathrm{HO}_{2}{ }^{-}(\%)$ of $\sim 40$ is in the same range as the data from previous sections. It is noteworthy that, in the potential widow of interest, $0.5-0.7 \mathrm{~V}_{\mathrm{RHE}}$, the other two materials PANI-TS-TC and PANINi-TS-TC yield high current density (Figure $3 e$ ) and better selectivity in hydrogen peroxide production (Figure 3f) by approaching the state-of-the-art material, Vulcan. We note that, being a process at the cathode of the electrolysis cell, the electrode potential of ORR must be as high as possible to require the minimum electrical energy, since the cell voltage is given by the relationship $\mathrm{U}_{\text {(cell) }}=\mathrm{E}_{\text {(anode) }}-\mathrm{E}_{\text {(cathode) }}$. Specifically, at $0.6 \mathrm{~V}_{\mathrm{RHE}}$, the selectivity towards the two-electron reduction is $\mathrm{HO}_{2}{ }^{-}(\%)=65,70$ and 75 for PANI-TSTC, PANI-Ni-TS-TC and Vulcan, respectively. The main outcome of these three previous studies is that after polymerization, heat treatment under air and inert atmosphere, the latter step allows one to target materials with a higher performance in terms of current density and selectivity towards the oxygen-to-hydrogen peroxide electro-conversion. This is achieved with polyaniline materials modified or not by nickel species. It is well-known that the electron transfer on graphitic materials strongly depends on the physicochemical and electronic properties of the electrode materials; however, the high electrocatalytic activity relies on the surface chemistry [42,43]. On the basis of our previous Raman and FTIR spectroscopy analysis $[19,20]$, the relationship between the electron transfer and the crystallinity or nature of graphite species is discussed. For PANI-Ni, the most relevant electrocatalyst for $\mathrm{HO}_{2}{ }^{-}$production, the Raman spectra exhibit four bands. Two bands corresponding to $\mathrm{G}$ and $\mathrm{D}$ were found between 1589 and $1594 \mathrm{~cm}^{-1}$ and between 1311 
and $1331 \mathrm{~cm}^{-1}$, respectively. The band $\mathrm{G}$ reflects the degree of graphitization and the D band is related to edge defects and disordered induce feature. The third and fourth bands that appeared at fixed frequency at 1480 and $1165 \mathrm{~cm}^{-1}$ are characteristic of amorphous carbon and the presence of nanocrystalline diamond. The obtained $A_{D} / A_{G}$ ratio was 3.1 with an in-plane crystallite size $\left(L_{a}\right)$ of 14.8. After thermal stabilization and heat treatment steps, the $G$-band position shifts and the intensity ratio of $A_{D} / A_{G}$ decreases to 2.2, while the in-plane crystallite size increases to $20.9 \mathrm{~nm}$, indicating the transformation of graphite to an ordered structure with nanocrystalline graphite formation [44]. The $A_{D} / A_{G}$ ratio decreasing could reflect the sp2 carbon fraction raise and thus may be beneficial for the $\mathrm{O}_{2}$ molecule adsorption. Such observation is in line with the XPS result that showed the increase in $\mathrm{C}=\mathrm{C}$ compared to $\mathrm{C}-\mathrm{O}$ and $\mathrm{C}=\mathrm{O}$ and after calcination [20]. It is widely recognized that the enhancement of the electron transfer rate is related to the defect engineering and to the higher density of step edges on the electrode surface as well as graphite distortion [42,45]. Earlier studies have demonstrated that the presence of quinone groups on the carbon surface, especially the semi-quinone radical anions $\left(\mathrm{Q}^{\bullet-}\right)$, play a crucial role for the enhancement of $\mathrm{HO}_{2}^{-}$production in an alkaline medium; the mechanism described by Equations (12)-(16) [46,47]. When $\mathrm{O}_{2}$ is adsorbed on the surface of the electrode, $\mathrm{O}_{2}{ }^{\bullet-}$ is formed by Equation (13), which remains adsorbed on the electrode surface and can be protonated by $\mathrm{H}_{2} \mathrm{O}$ (Equation (14)). However, in alkaline media, $\mathrm{HO}_{2}{ }^{\bullet-}$ (ads) possesses higher $\mathrm{pKa}$ than $\mathrm{HO}_{2}{ }^{-}$(aq), which hindered its protonation, leading to the formation of hydrogen peroxide as a final product [48].

$$
\begin{gathered}
\mathrm{Q}+\mathrm{e}^{-} \rightarrow \mathrm{Q}^{\bullet-} \\
\mathrm{Q}^{\bullet-}+\mathrm{O}_{2} \rightarrow{\mathrm{Q}-\mathrm{O}_{2}^{\bullet-} \text { (ads) }}^{\bullet}
\end{gathered}
$$

Either

$$
\begin{gathered}
\mathrm{Q}^{-\mathrm{O}_{2}}{ }^{\bullet-}+\mathrm{H}_{2} \mathrm{O} \rightarrow \mathrm{Q}+\mathrm{HO}_{2}{ }^{\left.{ }^{(a d s}\right)}+\mathrm{OH}^{-} \\
\mathrm{HO}_{2}{ }^{\bullet}{ }_{(\text {ads })}+\mathrm{e}^{-} \rightarrow \mathrm{HO}_{2}{ }^{-}{ }_{(\mathrm{aq})}
\end{gathered}
$$

$\mathrm{Or}$

$$
\mathrm{Q}^{-} \mathrm{O}_{2}^{\bullet-}+\mathrm{H}_{2} \mathrm{O}+\mathrm{e}^{-} \rightarrow \mathrm{Q}+\mathrm{HO}_{2}^{-}+\mathrm{OH}^{-}
$$

where $\mathrm{Q}$ is the surface quinone species.

Based on this finding, we selected the most efficient materials, PANI-TS-TC and PANI-Ni-TS-TC, for further studies in order to get closer to the real conditions of use in electrolyzers. The state-of-the art material, Vulcan, was also used for comparison.

Therefore, to confirm the observed efficiency with the RRDE method, hydrogen peroxide was monitored spectrophotometrically after bulk electrolysis, which was performed by loading the electrocatalysts onto gas diffusion electrodes (3D network of carbon microfibers, carbon paper MGL370, Fuel Cell Earth LLC) and testing them in a H-type cell made of two compartments separated by a hydroxide anion exchange membrane. Figure 4 a shows the obtained potentiostatic curves of current vs. time at an applied potential of $0.6 \mathrm{~V}_{\mathrm{RHE}}$ where the electrocatalyst loading was $0.5 \mathrm{mg} \mathrm{cm} \mathrm{cm}^{-2}$ and the electrode size was $4 \mathrm{~cm}^{2}$. The control experiment was performed using the blank material (no deposit of the catalyst ink), which does not show any significant current. The electrocatalyst PANI-TS-TC maintains a stable current of an absolute value of $100 \mathrm{~mA}$, while the major loss of the current is observed for Vulcan. The decrease in the current after a certain duration for electrocatalysts delivering high currents could be due to the mass transport issues in the vicinity of the electrode surface, particularly for such 3D supports. To find the best condition of UV-vis titration, we recorded U-Vis spectra in full range of 300-900 nm. Figure $4 \mathrm{~b}$ shows the UV-vis spectra for solutions obtained at different times of electrolysis for the material PANI-Ni-TS-TC and after neutralization by sulfuric acid plus potassium titanium oxalate to complex with hydrogen peroxide. Meanwhile, standard solutions were prepared and tested, as reported in Figure $4 \mathrm{c}$. Figure $4 \mathrm{~d}$ highlights that there is a linear correlation at the maximum wavelength of $\lambda=390 \mathrm{~nm}$. The series of control experiments confirm that this wavelength from the 
pertitanic acid complex between potassium titanium oxalate and hydrogen peroxide can be used to selectively quantify any hydrogen peroxide, similar to previous reports [26-29]. The productivity of hydrogen peroxide as quantified by the UV-vis assays is displayed in Figure 4c. The faradaic efficiency, as the ratio between the electrical charge corresponding the quantified hydrogen peroxide and the total charge (from Figure $4 \mathrm{a}$ ), is shown in Figure $4 \mathrm{f}$. Comparative data with the literature are reported in Table S1. Specifically, the production rate is $34 \pm 4,974 \pm 83,1057 \pm 64$ and $1042 \pm 74 \mu_{m^{2} l_{2}{ }_{2}} \mathrm{~h}^{-1}$ for Blank, PANI-TS-TC, PANI-Ni-TS-TC, and Vulcan, respectively. Otherwise, it is $521 \pm 37,487 \pm 42$ and $529 \pm 32$ mol $_{\mathrm{H} 2 \mathrm{O} 2} \mathrm{~kg}^{-1} \mathrm{cat}^{-1}$ for Vulcan, PANI-TS-TC and PANI-Ni-TS-TC, respectively. Taking into account the electrode area, the production rate is $130 \pm 9,122 \pm 10$ and $132 \pm 8 \mathrm{~mol}_{\mathrm{H} 2 \mathrm{O} 2} \mathrm{~kg}^{-1}{ }_{\text {cat }} \mathrm{cm}^{-2}$ for the same order. The faradaic efficiency of PANI-TS-TC and PANI-Ni-TS-TC is similar, FE $=(58 \pm 2) \%$, while that of Vulcan is FE $=(68 \pm 1) \%$. The discrepancy in terms of the faradaic efficiency between the RRDE method and the bulk electrolysis followed by UV-vis titration means that the electrocatalytic behavior using a thin-film method is not necessary to what is happening in real systems that use threedimensional supports such as gas diffusion electrodes $[49,50]$. For comparison with the existing data in the literature (see Table S1 for all metrics), the faradaic efficiency is below the recorded values of $94-95 \%[8,51]$, but is comparable to up-to-date data gathered in Ref. [3], e.g., faradaic efficiency of 70-87\% [52,53].

\subsection{Structural Analysis}

The three obtained materials after polymerization $\left(5^{\circ} \mathrm{C}, 13 \mathrm{~h}\right)$, stabilization (air, $350{ }^{\circ} \mathrm{C}$ $2 \mathrm{~h}$ ) and calcination $\left(\mathrm{N}_{2}, 900{ }^{\circ} \mathrm{C}, 6 \mathrm{~h}\right)$ were analyzed by SEM, EDX and XRD to obtain structure information. Other extensive characterization results can be found in Ref. [20]. To better visualize the formed structures, backscattered SEM images were recorded at different magnifications as displayed in Figure 5a1 to 5c2. The comparison between the control material PANI-TS-TC (Figure 5a1,a2) and those containing the metallic species PANI-Ni-TS-TC (Figure 5b1,b2) and PANI-Co-TS-TC (Figure 5c1,c2) shows the presence of micro-structured particles of different shape and size. For polyaniline-based materials, it is known that the thermal treatment under an inert atmosphere of argon or nitrogen at $600-1200{ }^{\circ} \mathrm{C}$ will trigger the rearrangement of the different atoms to create new bonds of carbon-carbon $(\mathrm{C}-\mathrm{C}, \mathrm{C}=\mathrm{C}, \mathrm{C}-\mathrm{H}$ ) and carbon-nitrogen (pyridinic-N, pyrrolic-N, and graphitic-N) in a nanostructured network that has different levels of electrical conductivity, number of active sites and electrocatalytic kinetics [18,20,54-58]. In order to obtain a qualitative analysis of the nature of the structures formed with metallic species, in-depth analysis was conducted by EDX.

Figure 6a,b show the obtained EDX spectra, backscattered SEM images and the mapping. A closer observation conforms the formation of nickel-sulphur or cobalt-sulphur species and that there is no other overlapping between the signals of the metals and oxygen, carbon or nitrogen. For PANI-Ni-TS-TC, the atomic ratio of Ni/S is $1.6 \pm 0.1$, which suggests the formation of $\mathrm{Ni}_{3} \mathrm{~S}_{2}$ phase, while for PANI-Co-TS-TC, the atomic ratio of $1.2 \pm 0.1$ is in line with the formation of $\mathrm{Co}_{9} \mathrm{~S}_{8}$ species [41]. It was previously observed that the length of the tip of the $\mathrm{Ni}_{3} \mathrm{~S}_{2}$ particles increases with the duration of the calcination step [20], explained by the so-called vapor-liquid-solid (VLS) mechanism of growth, which involves a vapor of nickel-sulfur, meaning that the super-saturation and nucleation at the liquid/solid interface leads to axial crystal growth [59].

XRD results are reported in Figure 7a,b. For PANI-Ni-TS-TC, the suggested structure of $\mathrm{Ni}_{3} \mathrm{~S}_{2}$ from EDX analysis is confirmed by its main diffraction peaks at $2 \theta=22^{\circ}, 31^{\circ}$, $38^{\circ}, 44^{\circ}, 50.0^{\circ}$ and 55 for (101), (110), (003)/(021), (202), (113)/(211) and (122), respectively (JCPDS $n^{\circ} 44-1418$ ) [60-65]. This structure co-exists with Ni (JCPDS 03-1051). For PANI-CoTS-TC, $\mathrm{Cog}_{9} \mathrm{~S}_{8}$ (JCPDS 86-2273) co-exists with Co (JCPDS 15-0806). It can be concluded that the electrocatalysts are heterogeneous. It will be interesting in future studies to obtain pure phases of each of these compounds and to assess how the efficiencies in ORR in hydrogen peroxide production change. 

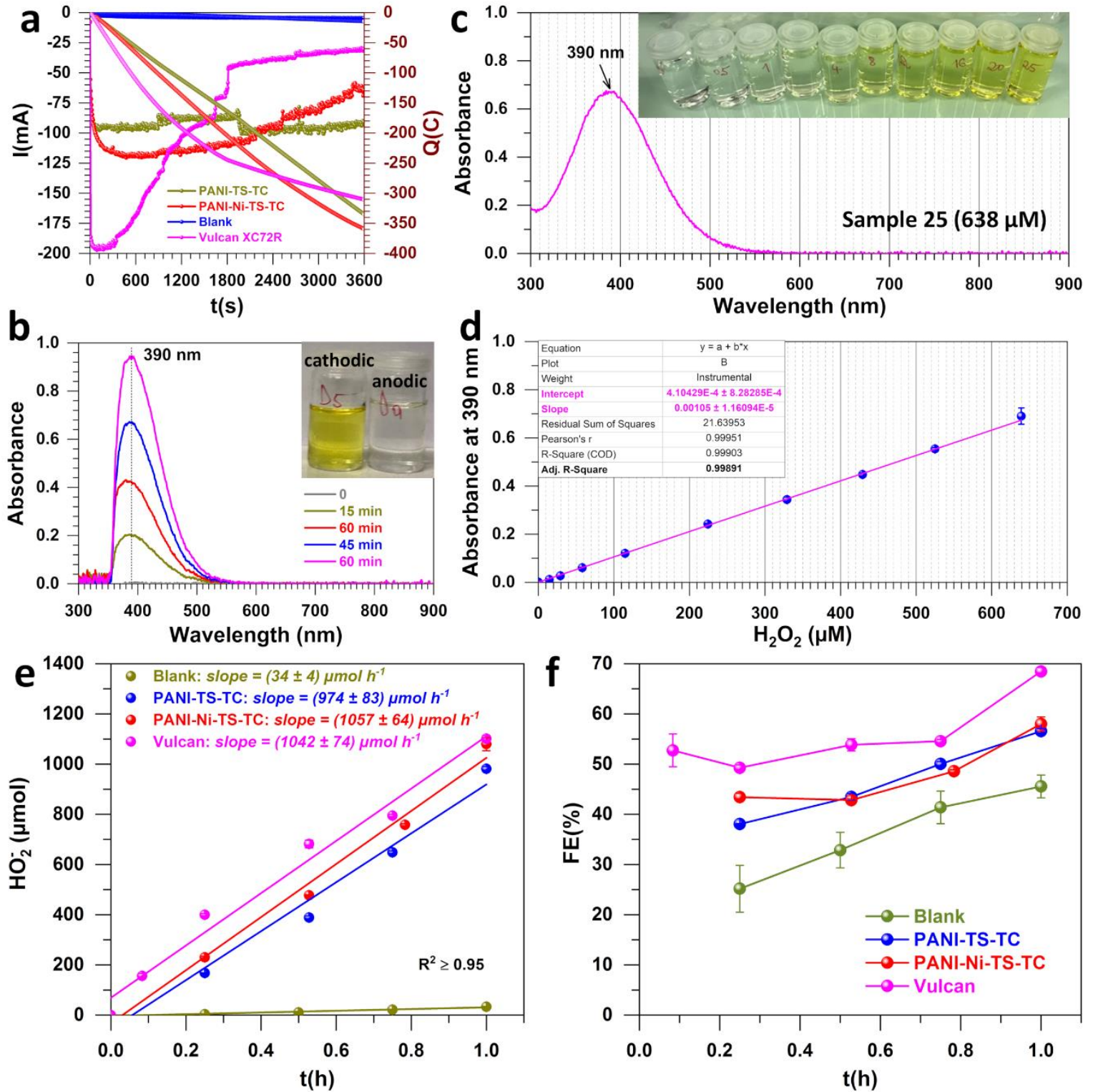

Figure 4. Bulk electrolysis and electroanalysis. (a) Electrical charge passed during the potentiostatic electrolysis at an applied potential of $0.6 \mathrm{~V}_{\mathrm{RHE}}$ (iR-uncorrected). (b) UV-vis spectra of the anodic compartment at different times of the electrolysis (aliquot was neutralized by sulfuric acid before addition of potassium titanium oxalate solution). (c) UV-vis spectrum of hydrogen peroxide (638 $\mu \mathrm{M})$ in the presence of sulfuric and potassium titanium oxalate solution: inset shows the color of the solution in the presence of increasing concentration of hydrogen peroxide. (d) Calibration curves from UV-vis assays at $390 \mathrm{~nm}$ and from solutions of panel (c). (e) Hydrogen peroxide productivity as quantified by the UV-vis assays. (f) Faradaic efficiency. The electrocatalyst loading was $0.5 \mathrm{mg} \mathrm{cm}^{-2}$ and the electrode size was $4 \mathrm{~cm}^{2}$. The blank electrode was bare carbon paper MGL370 (Fuel Cell Earth LLC). Error bars represent $1 \mathrm{SD}(\mathrm{n} \geq 3)$. 


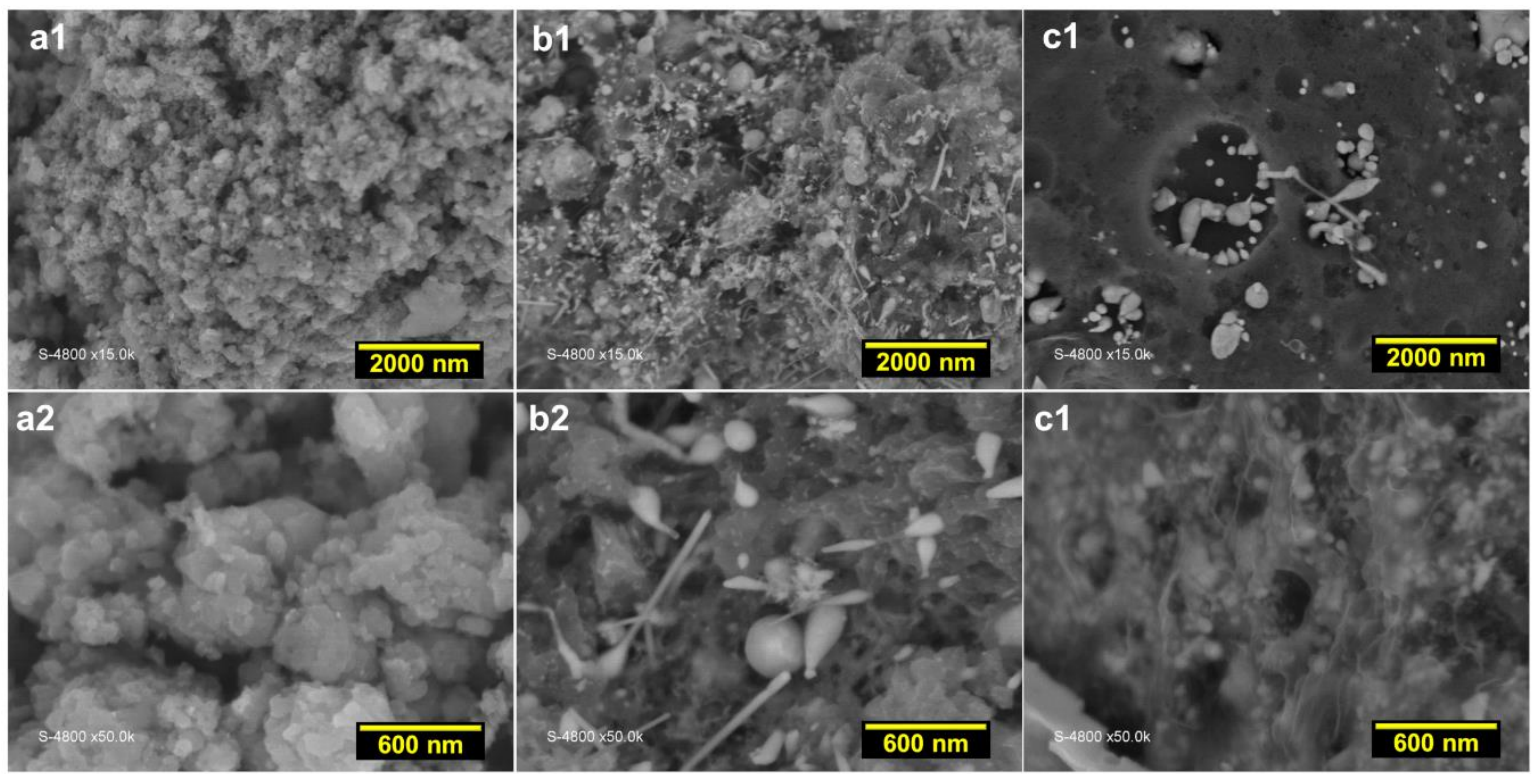

Figure 5. SEM characterization of the materials obtained after polymerization $\left(5{ }^{\circ} \mathrm{C}, 13 \mathrm{~h}\right)$, stabilization (air, $350{ }^{\circ} \mathrm{C}, 2 \mathrm{~h}$ ) and calcination $\left(\mathrm{N}_{2}, 900{ }^{\circ} \mathrm{C}, 6 \mathrm{~h}\right.$ ): backscattered SEM images at different magnification for: (a1,a2) PANI-TS-TC, (b1,b2) PANI-Ni-TS-TC, and (c1,c2) PANI-Co-TS-TC.

a
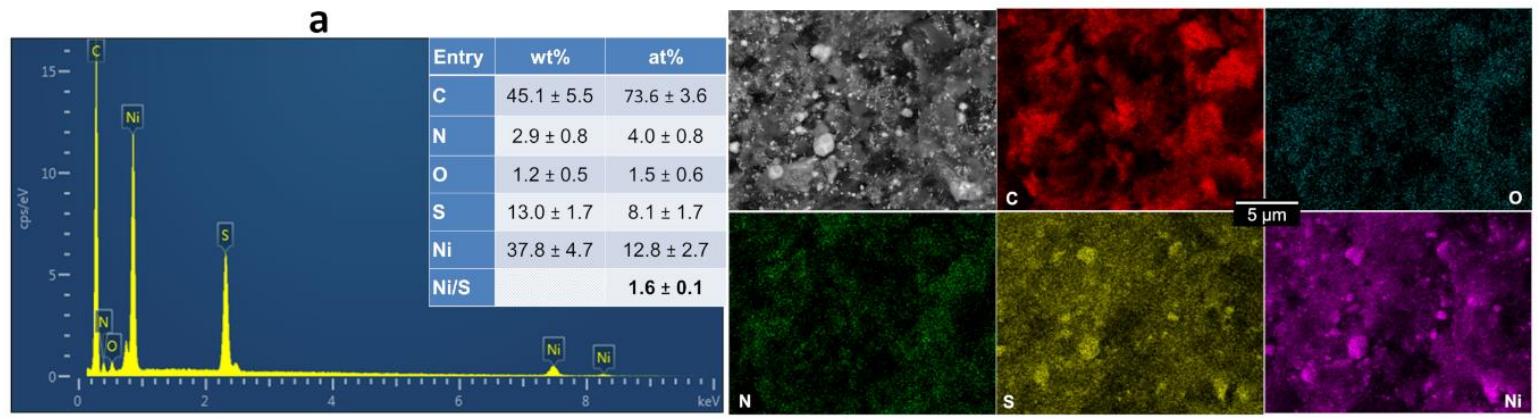

b

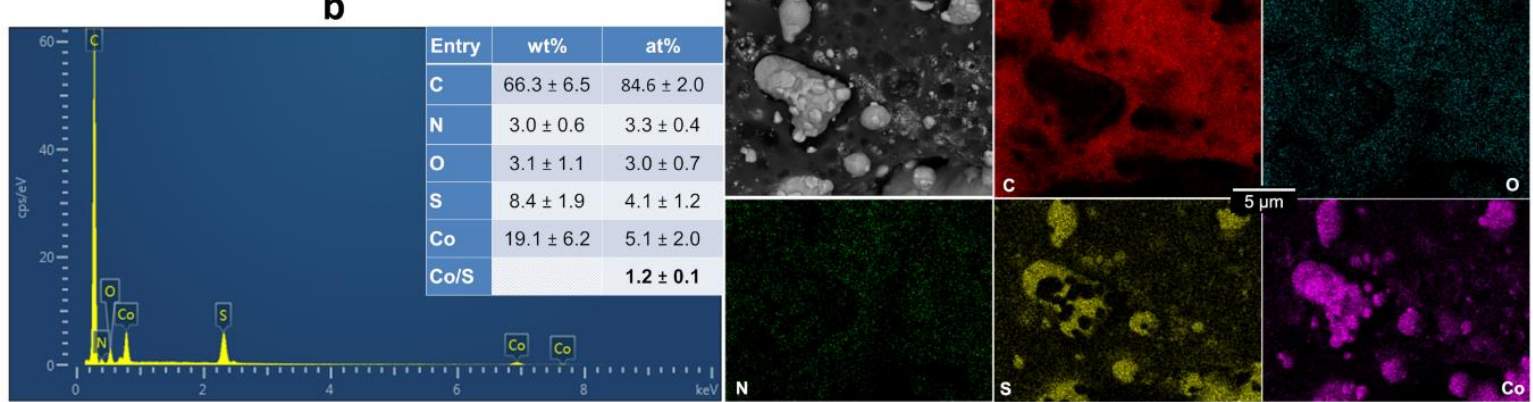

Figure 6. Materials obtained after polymerization $\left(5^{\circ} \mathrm{C}, 13 \mathrm{~h}\right)$, stabilization (air, $\left.350{ }^{\circ} \mathrm{C}, 2 \mathrm{~h}\right)$ and calcination $\left(\mathrm{N}_{2}, 900^{\circ} \mathrm{C}, 6 \mathrm{~h}\right)$ : EDX spectra, backscattered SEM images plus EDX maps of: (a) PANINi-TS-TC, and (b) PANI-Co-TS-TC. 

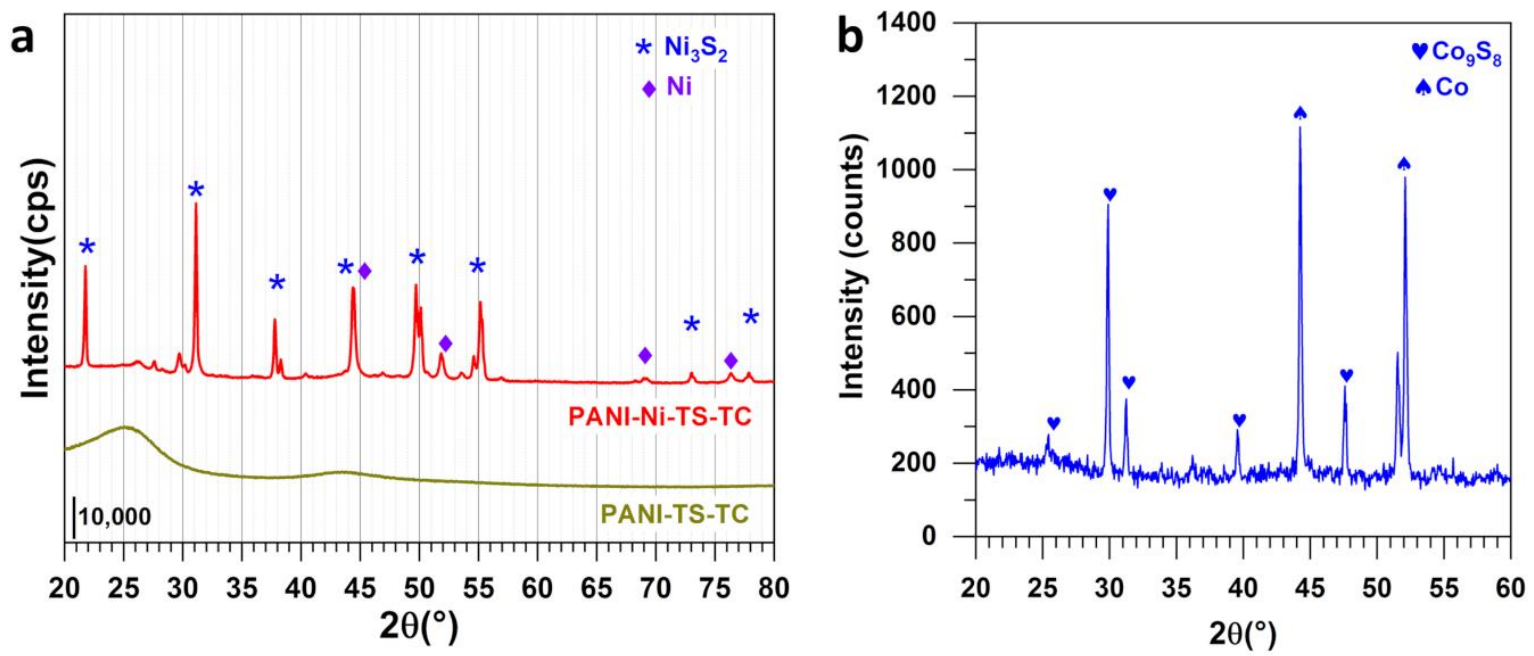

Figure 7. XRD patterns the electrocatalysts obtained after polymerization $\left(5{ }^{\circ} \mathrm{C}, 13 \mathrm{~h}\right)$, stabilization (air, $350^{\circ} \mathrm{C}, 2 \mathrm{~h}$ ) and calcination $\left(\mathrm{N}_{2}, 900{ }^{\circ} \mathrm{C}, 6 \mathrm{~h}\right.$ ): (a) PANI-TS-TC and PANI-Ni-TS-TC, and (b) PANI-Co-TS-TC.

\section{Conclusions}

In this study, we investigated the applicability of materials derived from the conducting polymer polyaniline (PANI) for oxygen-to-hydrogen peroxide electro-conversion in an alkaline medium. Indeed, a recent procedure (Front. Chem. 2020, 8, Article number 385) highlighted the formation of self-supported electrocatalytic materials by the oxidative polymerization of aniline into polyaniline with notable performance when tested for the reduction of $\mathrm{H}_{2} \mathrm{O}$ to $\mathrm{H}_{2}$ in alkaline media. Herein, at each stage of the synthesis (polymerization $\left(5^{\circ} \mathrm{C}, 13 \mathrm{~h}\right)$, stabilization (air, $350{ }^{\circ} \mathrm{C}, 2 \mathrm{~h}$ ) and calcination $\left(\mathrm{N}_{2}, 900{ }^{\circ} \mathrm{C}\right.$, $6 \mathrm{~h})$ ), three materials of PANI, modified or not by nickel or cobalt species, were used to study the oxygen reduction reaction (ORR) and probe the selective two electrons pathway $\left(\mathrm{O}_{2}+\mathrm{H}_{2} \mathrm{O}+2 \mathrm{e}^{-} \rightarrow \mathrm{HO}_{2}{ }^{-}+\mathrm{HO}^{-} ; \mathrm{HO}_{2}{ }^{-}\right.$is a hydroperoxide anion, the most stable specie in alkaline electrolytes, $\left.\mathrm{pKa}\left(\mathrm{H}_{2} \mathrm{O}_{2} / \mathrm{HO}_{2}{ }^{-}\right)=11.75\right)$. We employed two complementary electroanalytical step-ups, namely a rotating ring-disk electrode (RRDE) and bulk electrolysis combined with UV-vis titration. Using the RRDE method, the selectivity towards hydrogen peroxide production was higher than $60 \%$ for polyaniline and nickel-modified polyaniline. The third step, the calcination $\left(\mathrm{N}_{2}, 900{ }^{\circ} \mathrm{C}, 6 \mathrm{~h}\right)$, produced the highest current density and selectivity of $65-80 \%$, which drops to $40 \%$ in the presence of cobalt where XRD analysis revealed the co-existence of $\mathrm{Co}_{9} \mathrm{~S}_{8}$ with $\mathrm{Co}$, while $\mathrm{Ni}_{3} \mathrm{~S}_{2}$ and $\mathrm{Ni}$ were the main species when the polymerization was performed in the presence of nickel salt. From the bulk electrolysis and the spectrophotometry, the production rate was $974 \pm 83$,

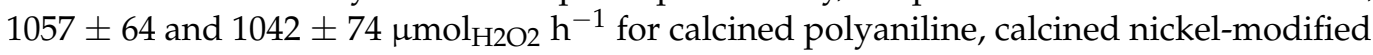
polyaniline and Vulcan XC72R (state-of-the-art electrocatalyst), respectively. These results correspond to $521 \pm 37,487 \pm 42$ and $529 \pm 32$ mol $_{\mathrm{H} 2 \mathrm{O} 2} \mathrm{~kg}^{-1}$ cat $\mathrm{h}^{-1}(130 \pm 9,122 \pm 10$ and $132 \pm 8 \mathrm{~mol}_{\mathrm{H} 2 \mathrm{O} 2} \mathrm{~kg}^{-1}$ cat $\mathrm{cm}^{-2}$ ) for Vulcan, calcined polyaniline and calcined nickelmodified polyaniline, respectively. The faradaic efficiency was 58-78\%. The structural analysis showed that the electrocatalysts are heterogeneous, so it would be worthwhile in future studies to target pure phases of each of the preceding compounds and to evaluate the influence on the efficiencies in ORR in hydrogen peroxide production. The present work contributes towards the engineering of efficient electrocatalysts derived from polymers for the decentralized electrosynthesis of hydrogen peroxide, which is of key importance in chemical industries. 


\begin{abstract}
Supplementary Materials: The following supporting information can be downloaded at: https:/ /www. mdpi.com/article/10.3390/polym14030607/s1, Figures S1-S8: Extended electrochemical characterization data; Table S1: Summary of reported electrocatalysts for hydrogen peroxide production in aqueous electrolyte.

Author Contributions: Conceptualization, Y.H.; Formal analysis, Y.H., S.K., M.-A.L., J.C., S.T. and D.C.; Investigation, Y.H., S.K., M.-A.L., J.C. and T.W.N.; Methodology, Y.H., S.K., M.-A.L., J.C., S.T., T.W.N. and D.C.; Project administration, Y.H.; Resources, Y.H., J.C, S.T. and D.C.; Supervision, Y.H.; Validation, Y.H., J.C., S.T., T.W.N. and D.C.; Writing-original draft, Y.H.; Writing-review and editing, S.K., M.-A.L., J.C., S.T., T.W.N. and D.C. All authors have read and agreed to the published version of the manuscript.
\end{abstract}

Funding: This research received no external funding.

Institutional Review Board Statement: Not applicable.

Informed Consent Statement: Not applicable.

Data Availability Statement: The data supporting the findings of this study are available within the paper. Any other relevant data are also available upon reasonable request from the corresponding author.

Acknowledgments: We thank Didier Cot, Bertrand Rebiere from IEM Montpellier Bernard for assistance during SEM and EDX measurements. The APC was funded by Polymers MDPI.

Conflicts of Interest: The authors declare no conflict of interest.

\title{
References
}

1. Campos-Martin, J.M.; Blanco-Brieva, G.; Fierro, J.L.G. Hydrogen Peroxide Synthesis: An Outlook beyond the Anthraquinone Process. Angew. Chem. Int. Ed. 2006, 45, 6962-6984. [CrossRef] [PubMed]

2. Perry, S.C.; Mavrikis, S.; Wang, L.; Ponce de León, C. Future perspectives for the advancement of electrochemical hydrogen peroxide production. Curr. Opin. Electrochem. 2021, 30, 100792. [CrossRef]

3. Jung, E.; Shin, H.; Hooch Antink, W.; Sung, Y.-E.; Hyeon, T. Recent Advances in Electrochemical Oxygen Reduction to $\mathrm{H}_{2} \mathrm{O}_{2}$ : Catalyst and Cell Design. ACS Energy Lett. 2020, 5, 1881-1892. [CrossRef]

4. Yang, S.; Verdaguer-Casadevall, A.; Arnarson, L.; Silvioli, L.; Čolić, V.; Frydendal, R.; Rossmeisl, J.; Chorkendorff, I.; Stephens, I.E.L. Toward the Decentralized Electrochemical Production of $\mathrm{H}_{2} \mathrm{O}_{2}$ : A Focus on the Catalysis. ACS Catal. 2018, 8, 4064-4081. [CrossRef]

5. Zhu, Q.; Pan, Z.; Hu, S.; Kim, J.-H. Cathodic Hydrogen Peroxide Electrosynthesis Using Anthraquinone Modified Carbon Nitride on Gas Diffusion Electrode. ACS Appl. Energy Mater. 2019, 2, 7972-7979. [CrossRef]

6. Siahrostami, S.; Verdaguer-Casadevall, A.; Karamad, M.; Deiana, D.; Malacrida, P.; Wickman, B.; Escudero-Escribano, M.; Paoli, E.A.; Frydendal, R.; Hansen, T.W.; et al. Enabling direct $\mathrm{H}_{2} \mathrm{O}_{2}$ production through rational electrocatalyst design. Nat. Mater. 2013, 12, 1137-1143. [CrossRef]

7. Zakaria, M.B.; Li, C.; Pramanik, M.; Tsujimoto, Y.; Hu, M.; Malgras, V.; Tominaka, S.; Yamauchi, Y. Nanoporous Mn-based electrocatalysts through thermal conversion of cyano-bridged coordination polymers toward ultra-high efficiency hydrogen peroxide production. J. Mater. Chem. A 2016, 4, 9266-9274. [CrossRef]

8. Xia, C.; Xia, Y.; Zhu, P.; Fan, L.; Wang, H. Direct electrosynthesis of pure aqueous $\mathrm{H}_{2} \mathrm{O}_{2}$ solutions up to $20 \%$ by weight using a solid electrolyte. Science 2019, 366, 226-231. [CrossRef]

9. Morandi, P.; Flaud, V.; Tingry, S.; Cornu, D.; Holade, Y. Tartaric acid regulated the advanced synthesis of bismuth-based materials with tunable performance towards the electrocatalytic production of hydrogen peroxide. J. Mater. Chem. A 2020, 8, 18840-18855. [CrossRef]

10. Sun, Y.; Silvioli, L.; Sahraie, N.R.; Ju, W.; Li, J.; Zitolo, A.; Li, S.; Bagger, A.; Arnarson, L.; Wang, X.; et al. Activity-Selectivity Trends in the Electrochemical Production of Hydrogen Peroxide over Single-Site Metal-Nitrogen-Carbon Catalysts. J. Am. Chem. Soc. 2019, 141, 12372-12381. [CrossRef]

11. Mase, K.; Yoneda, M.; Yamada, Y.; Fukuzumi, S. Efficient Photocatalytic Production of Hydrogen Peroxide from Water and Dioxygen with Bismuth Vanadate and a Cobalt(II) Chlorin Complex. ACS Energy Lett. 2016, 1, 913-919. [CrossRef]

12. Yu, T.; Breslin, C.B. Review-2D Graphene and Graphene-Like Materials and Their Promising Applications in the Generation of Hydrogen Peroxide. J. Electrochem. Soc. 2020, 167, 126502. [CrossRef]

13. Jung, E.; Shin, H.; Lee, B.-H.; Efremov, V.; Lee, S.; Lee, H.S.; Kim, J.; Hooch Antink, W.; Park, S.; Lee, K.-S.; et al. Atomic-level tuning of Co-N-C catalyst for high-performance electrochemical H2O2 production. Nat. Mater. 2020, 19, 436-442. [CrossRef]

14. Sheng, H.; Hermes, E.D.; Yang, X.; Ying, D.; Janes, A.N.; Li, W.; Schmidt, J.R.; Jin, S. Electrocatalytic Production of $\mathrm{H}_{2} \mathrm{O}_{2}$ by Selective Oxygen Reduction Using Earth-Abundant Cobalt Pyrite $\left(\operatorname{CoS}_{2}\right)$. ACS Catal. 2019, 9, 8433-8442. [CrossRef]

15. Zhu, Q.; Hinkle, M.; Kim, D.J.; Kim, J.-H. Modular Hydrogen Peroxide Electrosynthesis Cell with Anthraquinone-Modified Polyaniline Electrocatalyst. ACS EST Eng. 2021, 1, 446-455. [CrossRef] 
16. Isaji, T.; Abe, M.; Amaya, T.; Hirao, T. Hydrogen Peroxide Generation Using Polyaniline/Transition Metal Nanohybrid Electrodes. J. Inorg. Organomet. Polym. Mater. 2015, 25, 855-859. [CrossRef]

17. Rabl, H.; Wielend, D.; Tekoglu, S.; Seelajaroen, H.; Neugebauer, H.; Heitzmann, N.; Apaydin, D.H.; Scharber, M.C.; Sariciftci, N.S. Are Polyaniline and Polypyrrole Electrocatalysts for Oxygen $\left(\mathrm{O}_{2}\right)$ Reduction to Hydrogen Peroxide $\left(\mathrm{H}_{2} \mathrm{O}_{2}\right)$ ? ACS Appl. Energy Mater. 2020, 3, 10611-10618. [CrossRef]

18. Quílez-Bermejo, J.; Morallón, E.; Cazorla-Amorós, D. Polyaniline-Derived N-Doped Ordered Mesoporous Carbon Thin Films: Efficient Catalysts towards Oxygen Reduction Reaction. Polymers 2020, 12, 2382. [CrossRef] [PubMed]

19. Djara, R.; Holade, Y.; Merzouki, A.; Masquelez, N.; Cot, D.; Rebiere, B.; Petit, E.; Huguet, P.; Canaff, C.; Morisset, S.; et al. Insights from the Physicochemical and Electrochemical Screening of the Potentiality of the Chemically Synthesized Polyaniline. J. Electrochem. Soc. 2020, 167, 066503. [CrossRef]

20. Djara, R.; Holade, Y.; Merzouki, A.; Lacour, M.-A.; Masquelez, N.; Flaud, V.; Cot, D.; Rebiere, B.; van der Lee, A.; Cambedouzou, J.; et al. Nanostructured Carbon-Nitrogen-Sulfur-Nickel Networks Derived from Polyaniline as Bifunctional Catalysts for Water Splitting. Front. Chem. 2020, 8, 385. [CrossRef] [PubMed]

21. Holade, Y.; Morais, C.; Servat, K.; Napporn, T.W.; Kokoh, K.B. Enhancing the available specific surface area of carbon supports to boost the electroactivity of nanostructured Pt catalysts. Phys. Chem. Chem. Phys. 2014, 16, 25609-25620. [CrossRef]

22. Shinozaki, K.; Zack, J.W.; Richards, R.M.; Pivovar, B.S.; Kocha, S.S. Oxygen Reduction Reaction Measurements on Platinum Electrocatalysts Utilizing Rotating Disk Electrode Technique: I. Impact of Impurities, Measurement Protocols and Applied Corrections. J. Electrochem. Soc. 2015, 162, F1144-F1158. [CrossRef]

23. Cassani, A.; Tuleushova, N.; Wang, Q.; Guesmi, H.; Bonniol, V.; Cambedouzou, J.; Tingry, S.; Bechelany, M.; Cornu, D.; Holade, Y. Fe-Modified Pd as an Effective Multifunctional Electrocatalyst for Catalytic Oxygen Reduction and Glycerol Oxidation Reactions in Alkaline Media. ACS Appl. Energy Mater. 2021, 4, 9944-9960. [CrossRef]

24. Garsany, Y.; Singer, I.L.; Swider-Lyons, K.E. Impact of film drying procedures on RDE characterization of Pt/VC electrocatalysts. J. Electroanal. Chem. 2011, 662, 396-406. [CrossRef]

25. Garsany, Y.; Baturina, O.A.; Swider-Lyons, K.E.; Kocha, S.S. Experimental Methods for Quantifying the Activity of Platinum Electrocatalysts for the Oxygen Reduction Reaction. Anal. Chem. 2010, 82, 6321-6328. [CrossRef] [PubMed]

26. Kosimaningrum, W.E.; Le, T.X.H.; Holade, Y.; Bechelany, M.; Tingry, S.; Buchari, B.; Noviandri, I.; Innocent, C.; Cretin, M. Surfactant- and Binder-Free Hierarchical Platinum Nanoarrays Directly Grown onto a Carbon Felt Electrode for Efficient Electrocatalysis. ACS Appl. Mater. Interfaces 2017, 9, 22476-22489. [CrossRef]

27. Patterson, B.D.; MacRae, E.A.; Ferguson, I.B. Estimation of hydrogen peroxide in plant extracts using titanium(IV). Anal. Biochem. 1984, 139, 487-492. [CrossRef]

28. Bonét-Maury, P. Titrage photocolorimétrique de faibles quantités d'eau oxygénée. C. R. Acad. Sci. 1944, 218, 117-119.

29. Lim, J.; Hoffmann, M.R. Substrate oxidation enhances the electrochemical production of hydrogen peroxide. Chem. Eng. J. 2019, 374, 958-964. [CrossRef]

30. Djara, R.; Lacour, M.-A.; Merzouki, A.; Cambedouzou, J.; Cornu, D.; Tingry, S.; Holade, Y. Iridium and Ruthenium Modified Polyaniline Polymer Leads to Nanostructured Electrocatalysts with High Performance Regarding Water Splitting. Polymers 2021, 13, 190. [CrossRef]

31. McCrory, C.C.L.; Jung, S.; Peters, J.C.; Jaramillo, T.F. Benchmarking Heterogeneous Electrocatalysts for the Oxygen Evolution Reaction. J. Am. Chem. Soc. 2013, 135, 16977-16987. [CrossRef] [PubMed]

32. Trasatti, S.; Petrii, O.A. Real surface area measurements in electrochemistry. Pure Appl. Chem. 1991, 63, 711-734. [CrossRef]

33. Holade, Y.; Sahin, N.; Servat, K.; Napporn, T.; Kokoh, K. Recent Advances in Carbon Supported Metal Nanoparticles Preparation for Oxygen Reduction Reaction in Low Temperature Fuel Cells. Catalysts 2015, 5, 310-348. [CrossRef]

34. Acres, G.J.K.; Frost, J.C.; Hards, G.A.; Potter, R.J.; Ralph, T.R.; Thompsett, D.; Burstein, G.T.; Hutchings, G.J. Electrocatalysts for fuel cells. Catal. Today 1997, 38, 393-400. [CrossRef]

35. Chai, G.-L.; Boero, M.; Hou, Z.; Terakura, K.; Cheng, W. Indirect Four-Electron Oxygen Reduction Reaction on Carbon Materials Catalysts in Acidic Solutions. ACS Catal. 2017, 7, 7908-7916. [CrossRef]

36. Gileadi, E. Electrods Kinetics for Chemists, Chemical Engineers, and Materials Scientists; John Wiley \& Sons, Ltd.: New York, NY, USA, 1993; p. 616.

37. Napporn, T.W.; Holade, Y.; Kokoh, B.; Mitsushima, S.; Mayer, K.; Eichberger, B.; Hacker, V. Chapter 9-Electrochemical Measurement Methods and Characterization on the Cell Level. In Fuel Cells and Hydrogen: From Fundamentals to Applied Research; Hacker, V., Mitsushima, S., Eds.; Elsevier: Amsterdam, The Netherlands, 2018; pp. 175-214.

38. Elgrishi, N.; Rountree, K.J.; McCarthy, B.D.; Rountree, E.S.; Eisenhart, T.T.; Dempsey, J.L. A Practical Beginner's Guide to Cyclic Voltammetry. J. Chem. Educ. 2017, 95, 197-206. [CrossRef]

39. Vork, F.T.A.; Barendrecht, E. The reduction of dioxygen at polypyrrole-modified electrodes with incorporated Pt particles. Electrochim. Acta 1990, 35, 135-139. [CrossRef]

40. Houache, M.S.E.; Cossar, E.; Ntais, S.; Baranova, E.A. Electrochemical modification of nickel surfaces for efficient glycerol electrooxidation. J. Power Sources 2018, 375, 310-319. [CrossRef]

41. Hajjar, P.; Lacour, M.-A.; Masquelez, N.; Cambedouzou, J.; Tingry, S.; Cornu, D.; Holade, Y. Insights on the Electrocatalytic Seawater Splitting at Heterogeneous Nickel-Cobalt Based Electrocatalysts Engineered from Oxidative Aniline Polymerization and Calcination. Molecules 2021, 26, 5926. [CrossRef] 
42. Favaro, M.; Perini, L.; Agnoli, S.; Durante, C.; Granozzi, G.; Gennaro, A. Electrochemical behavior of N and Ar implanted highly oriented pyrolytic graphite substrates and activity toward oxygen reduction reaction. Electrochim. Acta 2013, 88, 477-487. [CrossRef]

43. Tuci, G.; Zafferoni, C.; Rossin, A.; Milella, A.; Luconi, L.; Innocenti, M.; Truong Phuoc, L.; Duong-Viet, C.; Pham-Huu, C.; Giambastiani, G. Chemically Functionalized Carbon Nanotubes with Pyridine Groups as Easily Tunable N-Decorated Nanomaterials for the Oxygen Reduction Reaction in Alkaline Medium. Chem. Mater. 2014, 26, 3460-3470. [CrossRef]

44. Ferrari, A.C.; Robertson, J. Interpretation of Raman spectra of disordered and amorphous carbon. Phys. Rev. B 2000, 61, 14095-14107. [CrossRef]

45. Padya, B.; Kalita, D.; Jain, P.K.; Padmanabham, G.; Ravi, M.; Bhat, K.S. Self-organized growth of bamboo-like carbon nanotube arrays for field emission properties. Appl. Nanosci. 2012, 2, 253-259. [CrossRef]

46. Vikkisk, M.; Kruusenberg, I.; Joost, U.; Shulga, E.; Tammeveski, K. Electrocatalysis of oxygen reduction on nitrogen-containing multi-walled carbon nanotube modified glassy carbon electrodes. Electrochim. Acta 2013, 87, 709-716. [CrossRef]

47. Zhang, H.-J.; Li, H.; Li, X.; Zhao, B.; Yang, J. Electrocatalysis of oxygen reduction on carbon nanotubes with different surface functional groups in acid and alkaline solutions. Int. J. Hydrog. Energy 2014, 39, 16964-16975. [CrossRef]

48. Yang, H.-H.; McCreery, R.L. Elucidation of the Mechanism of Dioxygen Reduction on Metal-Free Carbon Electrodes. J. Electrochem. Soc. 2000, 147, 3420. [CrossRef]

49. Higgins, D.; Hahn, C.; Xiang, C.; Jaramillo, T.F.; Weber, A.Z. Gas-Diffusion Electrodes for Carbon Dioxide Reduction: A New Paradigm. ACS Energy Lett. 2018, 4, 317-324. [CrossRef]

50. Schröder, J.; Mints, V.A.; Bornet, A.; Berner, E.; Fathi Tovini, M.; Quinson, J.; Wiberg, G.K.H.; Bizzotto, F.; El-Sayed, H.A.; Arenz, M. The Gas Diffusion Electrode Setup as Straightforward Testing Device for Proton Exchange Membrane Water Electrolyzer Catalysts. JACS Au 2021, 1, 247-251. [CrossRef]

51. San Roman, D.; Krishnamurthy, D.; Garg, R.; Hafiz, H.; Lamparski, M.; Nuhfer, N.T.; Meunier, V.; Viswanathan, V.; Cohen-Karni, T. Engineering Three-Dimensional (3D) Out-of-Plane Graphene Edge Sites for Highly Selective Two-Electron Oxygen Reduction Electrocatalysis. ACS Catal. 2020, 10, 1993-2008. [CrossRef]

52. Sun, Y.; Sinev, I.; Ju, W.; Bergmann, A.; Dresp, S.; Kühl, S.; Spöri, C.; Schmies, H.; Wang, H.; Bernsmeier, D.; et al. Efficient Electrochemical Hydrogen Peroxide Production from Molecular Oxygen on Nitrogen-Doped Mesoporous Carbon Catalysts. ACS Catal. 2018, 8, 2844-2856. [CrossRef]

53. Chang, Q.; Zhang, P.; Mostaghimi, A.H.B.; Zhao, X.; Denny, S.R.; Lee, J.H.; Gao, H.; Zhang, Y.; Xin, H.L.; Siahrostami, S.; et al Promoting $\mathrm{H}_{2} \mathrm{O}_{2}$ production via 2-electron oxygen reduction by coordinating partially oxidized Pd with defect carbon. Nat. Commun. 2020, 11, 2178. [CrossRef] [PubMed]

54. Xiao, F.; Chen, Z.; Wu, H.; Wang, Y.; Cao, E.; Lu, X.; Wu, Y.; Ren, Z. Phytic acid-guided ultra-thin N,P co-doped carbon coated carbon nanotubes for efficient all-pH electrocatalytic hydrogen evolution. Nanoscale 2019, 11, 23027-23034. [CrossRef] [PubMed]

55. Xiong, Y.; Wang, Y.; Jiang, H.; Yuan, S. MWCNT Decorated Rich N-Doped Porous Carbon with Tunable Porosity for $\mathrm{CO}_{2} \mathrm{Capture}$ Molecules 2021, 26, 3451. [CrossRef] [PubMed]

56. Mahmood, A.; Xie, N.; Zhao, B.; Zhong, L.; Zhang, Y.; Niu, L. Optimizing Surface N-Doping of Fe-N-C Catalysts Derived from $\mathrm{Fe} /$ Melamine-Decorated Polyaniline for Oxygen Reduction Electrocatalysis. Adv. Mater. Interfaces 2021, 8, 2100197. [CrossRef]

57. Dong, Y.; Zhou, M.; Tu, W.; Zhu, E.; Chen, Y.; Zhao, Y.; Liao, S.; Huang, Y.; Chen, Q.; Li, Y. Hollow Loofah-Like N, O-Co-Doped Carbon Tube for Electrocatalysis of Oxygen Reduction. Adv. Funct. Mater. 2019, 29, 1900015. [CrossRef]

58. Xiang, X.; Li, X.; Huang, Z.; Gao, T.; Yuan, H.; Xiao, D. Sphere-and-Flake-Structured Cu, N Co-Doped Carbon Catalyst Designed by a Template-Free Method for Robust Oxygen Reduction Reaction. ChemElectroChem 2019, 6, 1078-1087. [CrossRef]

59. Wagner, R.S.; Ellis, W.C. Vapor-liquid-solid mechanism of single crystal growth. Appl. Phys. Lett. 1964, 4, 89-90. [CrossRef]

60. Zhang, Y.; Fu, J.; Zhao, H.; Jiang, R.; Tian, F.; Zhang, R. Tremella-like $\mathrm{Ni}_{3} \mathrm{~S}_{2} / \mathrm{MnS}$ with ultrathin nanosheets and abundant oxygen vacancies directly used for high speed overall water splitting. Appl. Catal. B Environ. 2019, 257, 117899. [CrossRef]

61. Wang, N.; Han, G.; Chang, Y.; Hou, W.; Xiao, Y.; Li, H. Preparing $\mathrm{Ni}_{3} \mathrm{~S}_{2}$ composite with neural network-like structure for high-performance flexible asymmetric supercapacitors. Electrochim. Acta 2019, 317, 322-332. [CrossRef]

62. Zhou, W.; Cao, X.; Zeng, Z.; Shi, W.; Zhu, Y.; Yan, Q.; Liu, H.; Wang, J.; Zhang, H. One-step synthesis of $\mathrm{Ni}_{3} \mathrm{~S}_{2}$ nanorod@Ni(OH) 2 nanosheet core-shell nanostructures on a three-dimensional graphene network for high-performance supercapacitors. Energy Environ. Sci. 2013, 6, 2216-2221. [CrossRef]

63. $\mathrm{Ou}, \mathrm{X}$;; Gan, L.; Luo, Z. Graphene-templated growth of hollow $\mathrm{Ni}_{3} \mathrm{~S}_{2}$ nanoparticles with enhanced pseudocapacitive performance. J. Mater. Chem. A 2014, 2, 19214-19220. [CrossRef]

64. Tian, D.; Chen, S.; Zhu, W.; Wang, C.; Lu, X. Metal-organic framework derived hierarchical Ni/ $\mathrm{Ni}_{3} \mathrm{~S}_{2}$ decorated carbon nanofibers for high-performance supercapacitors. Mater. Chem. Front. 2019, 3, 1653-1660. [CrossRef]

65. Jiang, N.; Tang, Q.; Sheng, M.; You, B.; Jiang, D.-E.; Sun, Y. Nickel sulfides for electrocatalytic hydrogen evolution under alkaline conditions: A case study of crystalline NiS, $\mathrm{NiS}_{2}$, and $\mathrm{Ni}_{3} \mathrm{~S}_{2}$ nanoparticles. Catal. Sci. Technol. 2016, 6, 1077-1084. [CrossRef] 